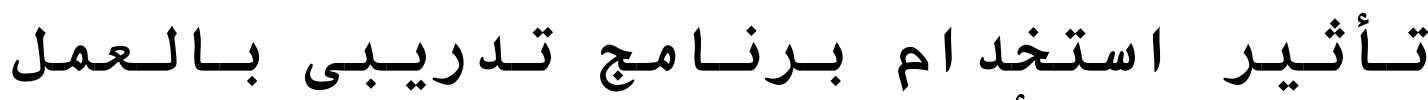

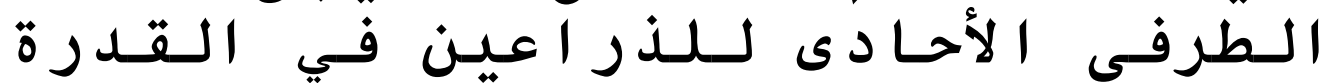

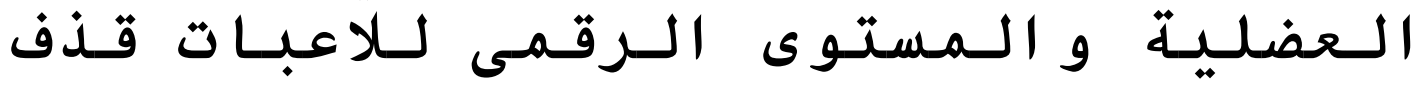

$$
\begin{aligned}
& \text { الـقـرم الـرقه }
\end{aligned}
$$

د/ إبراهيم حمدى يحي

مدرس بقسم مسابقات الميدان و المضمار

كلية التربية الرياضية - جامعة طنطا
أ.د/ خالد عبد الغفار الفلاح

أستاذ ألعاب القوى ورئيس قسم مسابقات الميدان

و المضمار كلية التربية الرياضية - جامعة طنطا

\footnotetext{
حسناء جلال عبد النبى سند

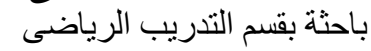

كلية التربية الرياضية - جامعة طنطا
} 


\section{تأثير استخدام برناهج تدريبى بالعمل الطرفى الأحادى للذراعين في القدرة العضلية والمستوى الرقتمى للاعبات قذف القرص لألمائ}

أ.د/ خالد عبد الغفار الفلاح(")

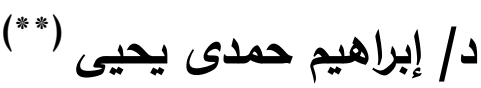

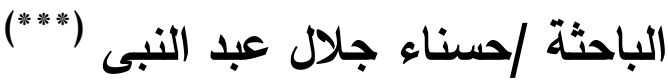

ملخص البحث

هدف البحث إلى تصميم برنامج تدريبى بليومترى بالعمل الطرفى الأحادى للذراعين للتعرف

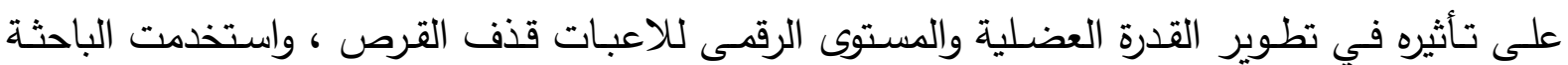

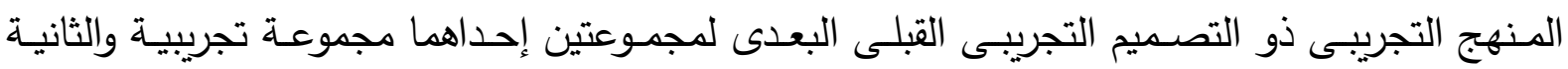

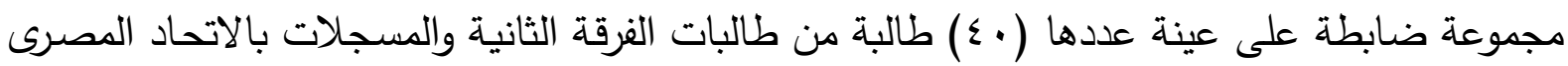

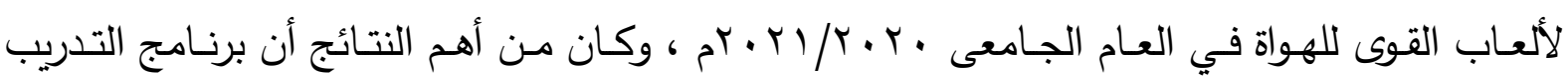

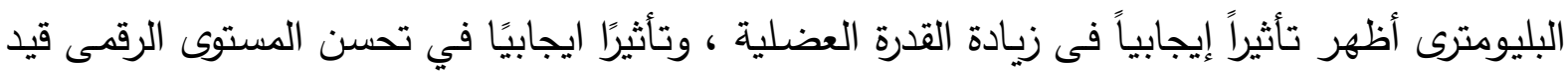
البحث . (البومتري

الكلمات الدالة : العمل الطرفى الأحادى - القدرة العضلية للذراعين - المستوى الرقمى لقذف القرص

\section{The Effect of Using Training Program with Unilateral Extremity Work of the Arms on Muscular Ability and the Digital Level of the Disc Throw Competition}

The aim of the research is to design a plyometric training program to identify its effect on developing the muscular ability and the digital level of the discus throwing players. Athletics) and registered with the Egyptian Amateur Athletics Federation in the academic year 2020/2021 AD, and one of the most important results was that the plyometric training program with unilateral and bilateral peripheral work showed a positive effect in increasing muscular capacity, and a positive effect in improving the digital level under discussion.

(") أستاذ ألعاب القوى ورئيس قسم مسابقات الميدان والمضمار بكلية التربية الرياضية - جامعة طنطا

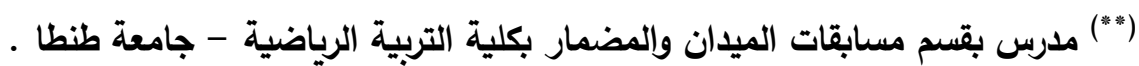

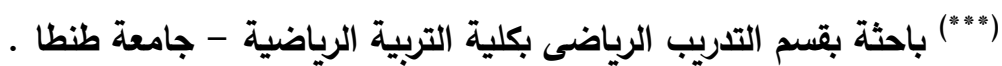


تطورت نظريـات وطرق التدريب الرياضسى فى السنوات الأخيرة تطورًا سريعًا ، تلك النظريات

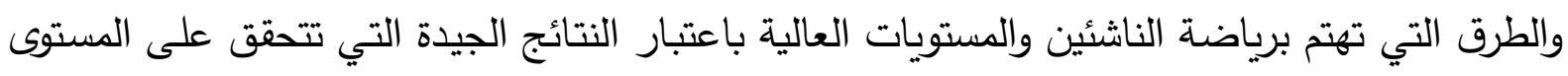

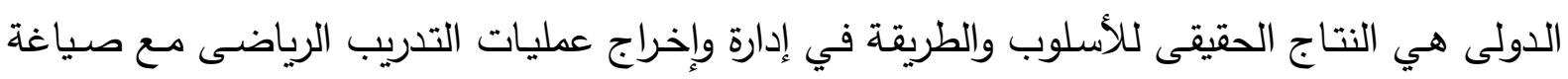

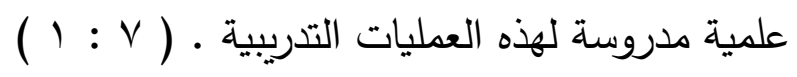

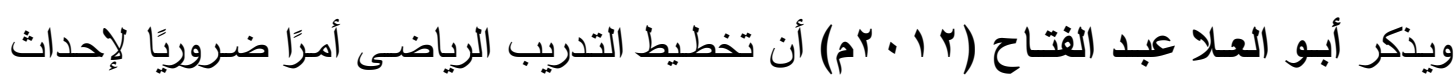

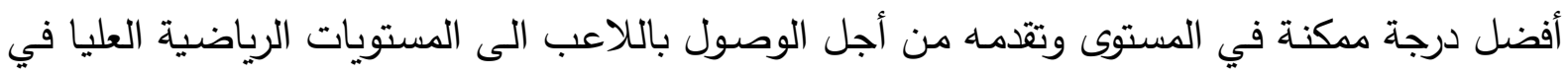

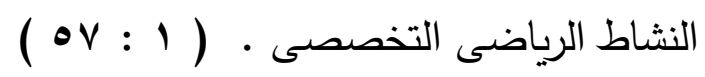

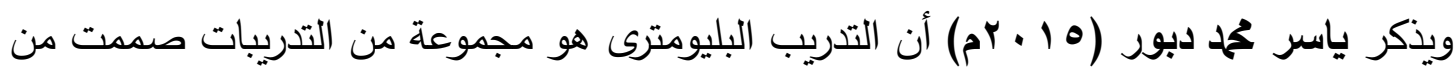

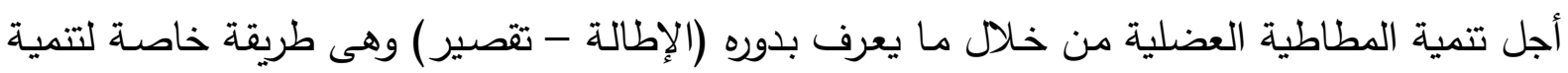

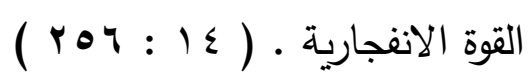

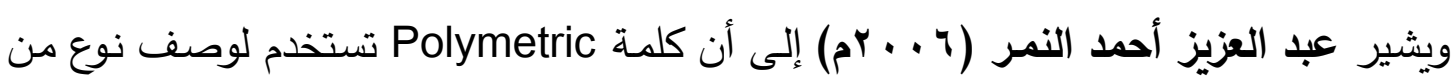

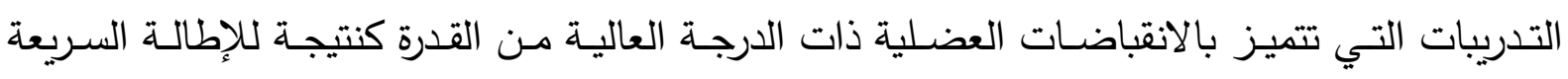

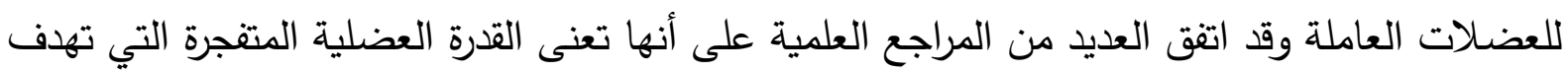

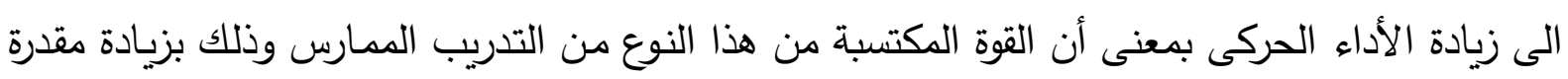

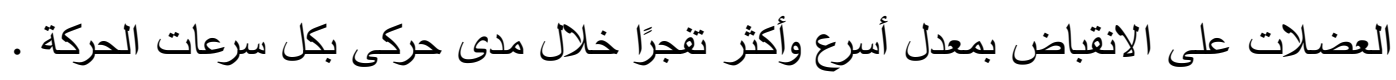
(11 $11-11 \%: 7)$

ويذكر كمال عبد الحميد اسماعيل (7 1 • ب م) أن القدرة Power هى نسبة العمل المؤدى أو قوة

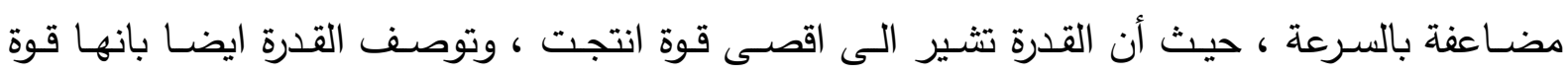

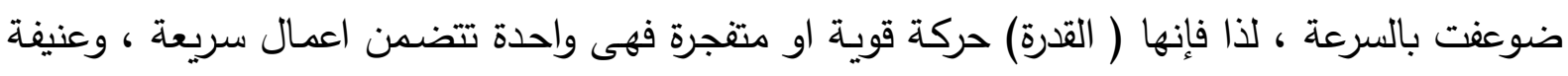

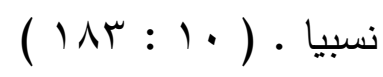

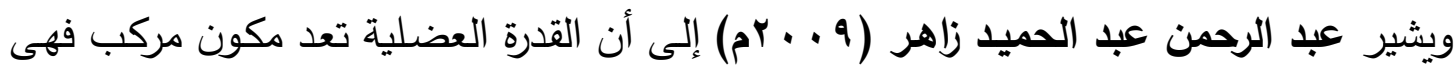

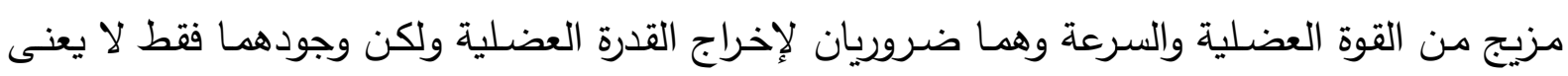

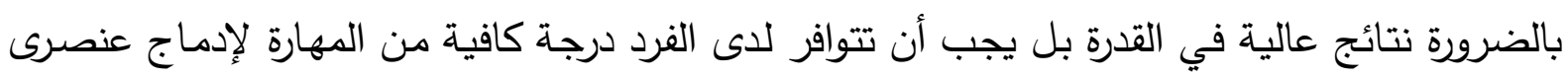

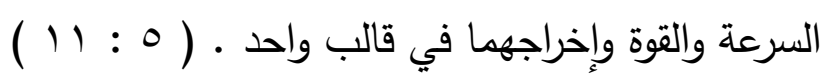

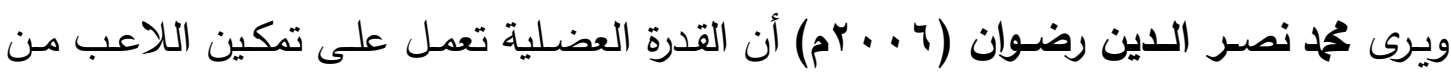

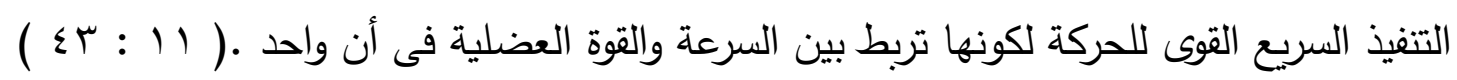

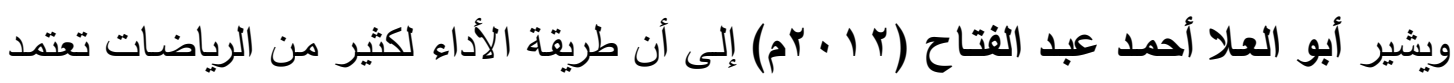

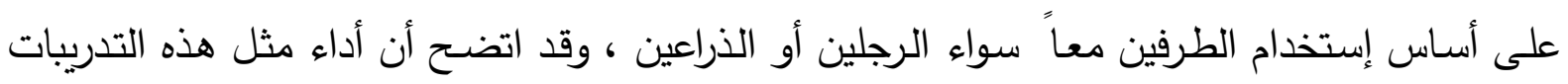




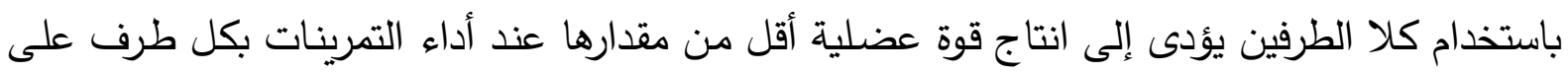
حدة أى بالطرف الأيمن وحده ثم الطرف الأيسر وحده ، كما يصاحب ذلك الك الإنخفاض فى مستوى الأداء الثنائى نقص فى النشاط الكهربى العضلى فى العضلات العاملة ويظهر هذا الثكل لدى غير المدربين

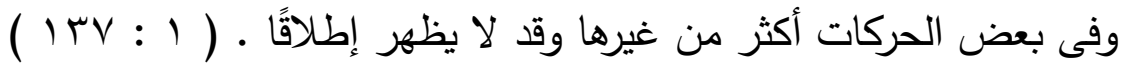

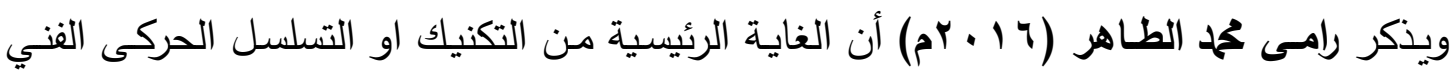
لمهارة قذف القرص هو توظيف صفات اللياقة البدنية والحركية للمتسابق من أجل تحقيق اقصى انجاز

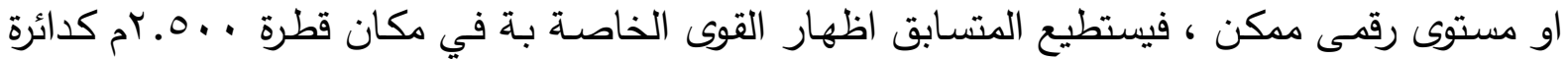

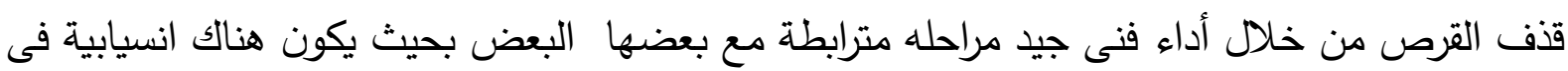

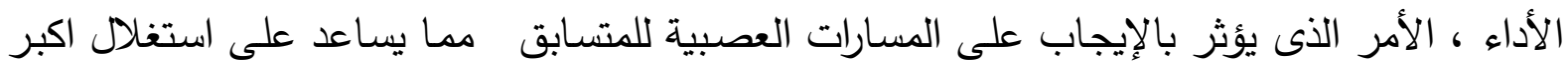

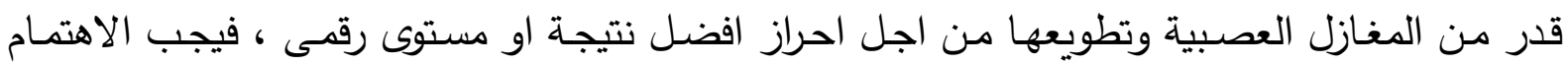
بتتمية الأداء الفني الحركى وتتمية الصفات البدنية حتى يكون هناك ما يسمى (بتوازن جرعة التدريب) . ( $7: \leq)$

ويشير فراج عبد الحميد توفيق (r . . rم) إلى أن مسابقات الرمى تعتبر من ضمن مسابقات

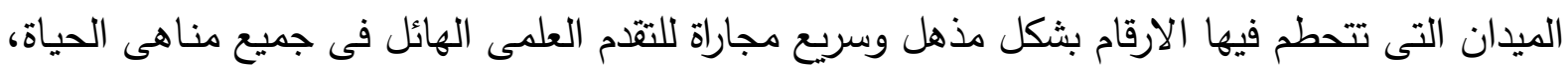

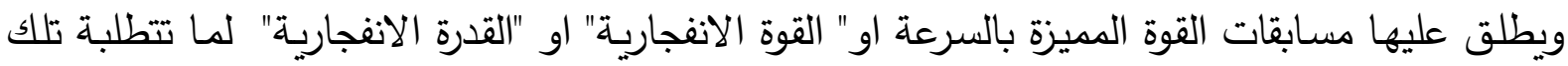

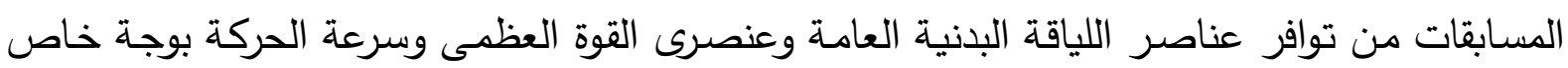

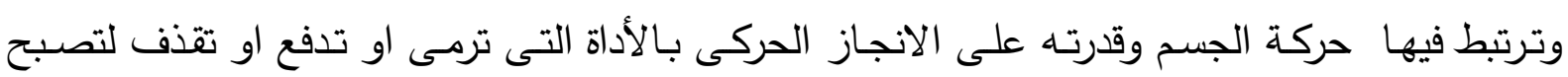

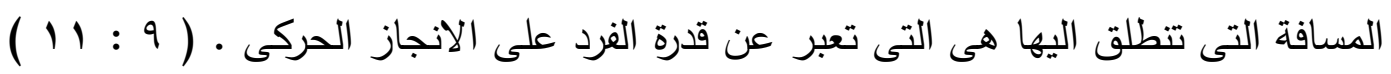

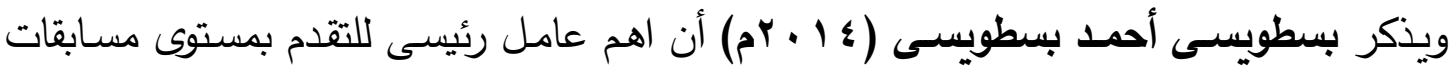

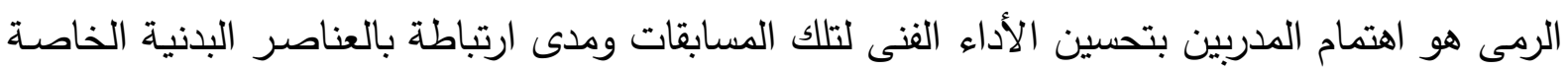

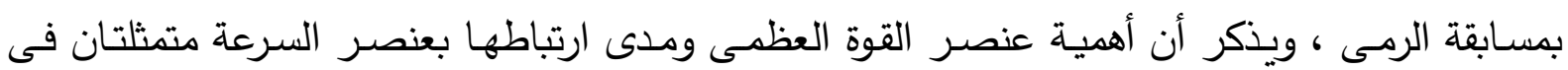

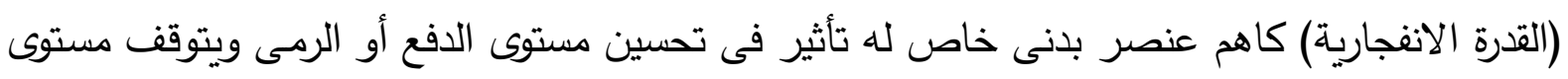

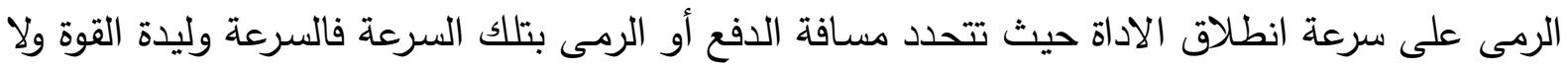

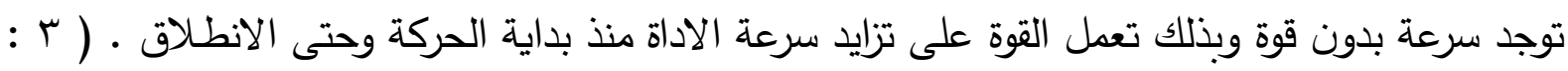

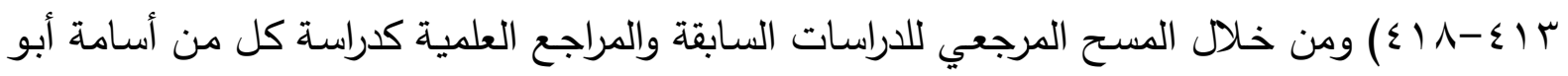

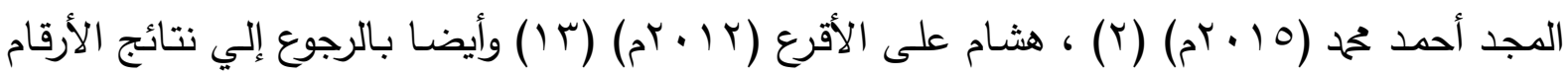

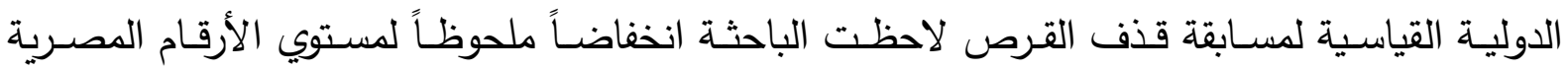

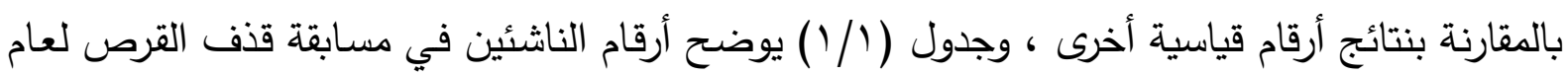
$\cdot 3 r \cdot 19$ 


\section{جدول (1)}

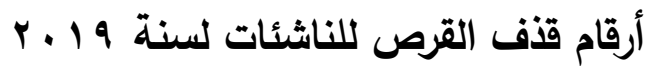

\begin{tabular}{|c|c|}
\hline المسافة & \\
\hline . . . . متر & الرقم المصرى \\
\hline צ. .9 \& متر & الرقم العربى \\
\hline متر VY.r. & الرقم العالمى \\
\hline
\end{tabular}

ولقد استرعي انتباه الباحثة التفاوت بين كل من المستوي الرقمي العالمي والعربى والمستوى

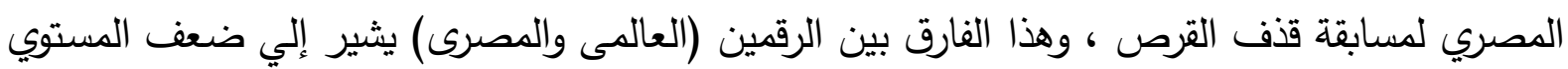

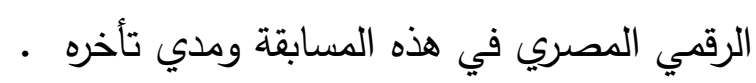
ومن خلال ملاحظة الباحثة لطالبات الفرقة الثانية بكلية التربية الرياضية - جامعة طنطا وجدت عدم مقدرتهن على تحقيق مستويات رقمية في مسابقة قذف القرص في الفصل الدراسى الأول

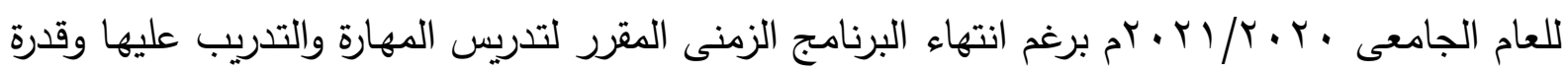

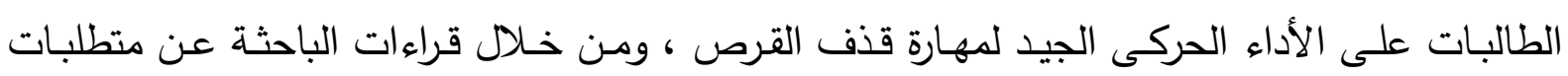

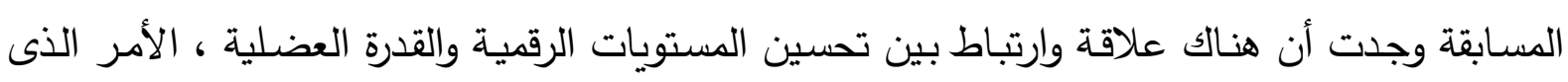

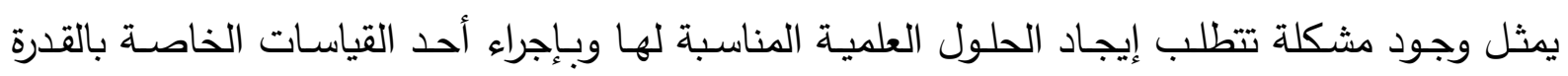
العضلية للذراعين المتمثلة في إختبار رمى الكرة لأبعد مسافة على عينة عشوائية من طالبات الفرقة

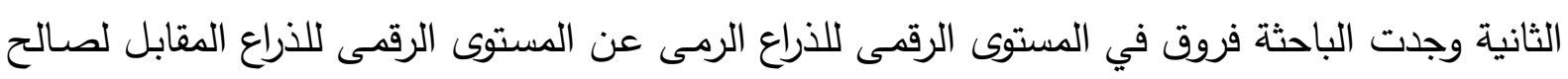

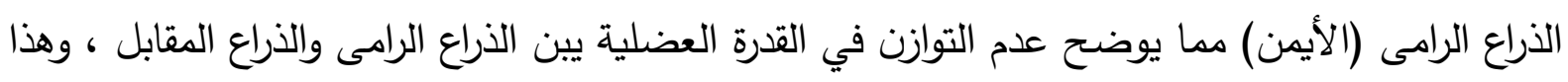

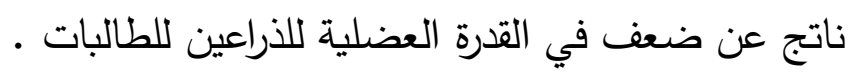
وهذا ما دفع الباحثة للقيام بدراسة تجريبية في محاولة للتغلب على هذه الظاهرة أو التقليل من

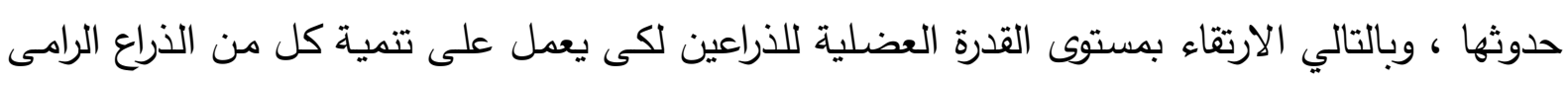

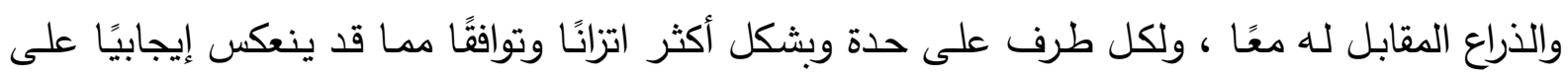

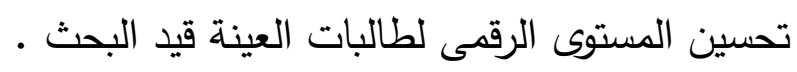

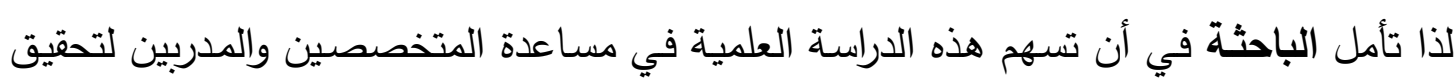

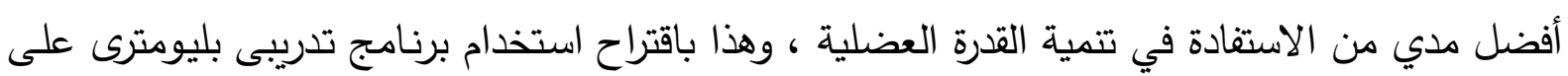

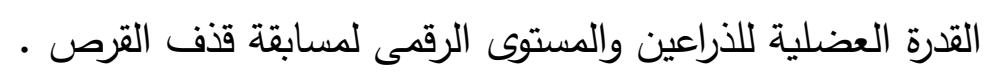




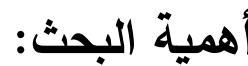

ا. . إمكانية تصميم برنامج تدريبى باستخدام التدريب البليومترى لمعرفة تأثيره على القدرة العضلية للذراعين والمستوى الرقمى لمسابقة قذف القرص. r. فتح مجال جديد للبحث العلمى فى المجال الرياضى لأسلوب من أساليب التدريب المستحدثة

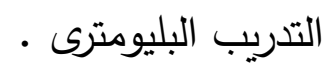

r. يعد البحث محاولة لرفع مستوى التدريب وزيادة فاعليته لتحسين المستوى الرقمى لمسابقة قذف . لـف

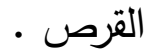
ء. الإستقادة مـن نتائج البحث وتوجيههـا لـدربى قذف القرص ورفع مستوى التدريب وتحسين

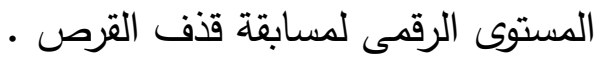

0. تحسين المستوى الرقمى لمسابقة قذف القرص لعينة البحث.

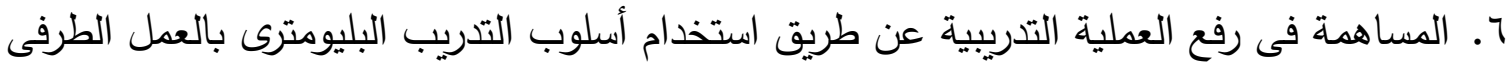

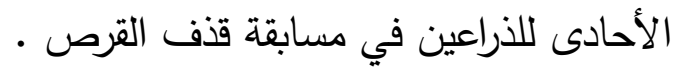

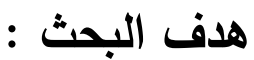

تصميم برنامج تدريبى بليومترى بالعمل الطرفى الأحادى للذراعين للتعرف على تأثيره في تطوير

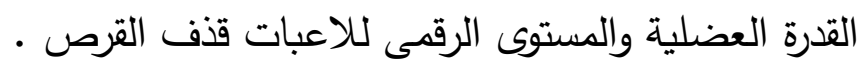

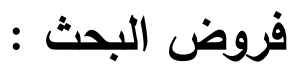

1- توجد فروق ذات دلالة إحصائية بين متوسطى القياسين القبلى والبعدى للمجموعة التجريبية في

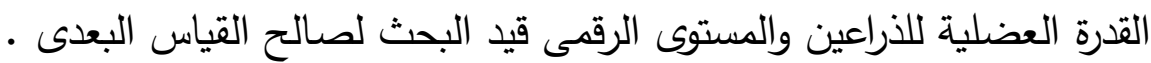

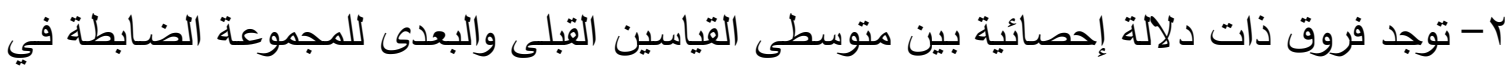

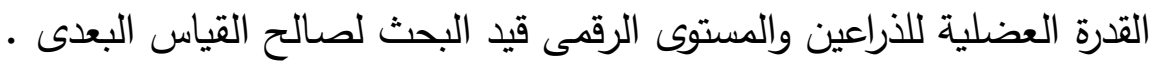
r- توجد فروق ذات دلالة إحصائية بين متوسطى القياسين القبلى والبعدى للدجموعتين التجريبية

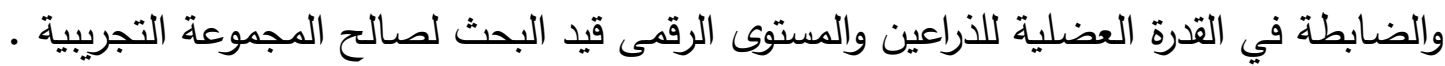

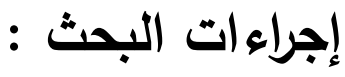
منهج البحث :

استخدمت الباحثة المنهج التجريبى ذو التصميم التجريبى القبلى البعدى لمجموعتين إحداهما مجموعة تجريبية والثانية مجموعة ضابطة وذلك لمناسبته لطبيعة البحث . مجتمع وعينة البحث : مجئ

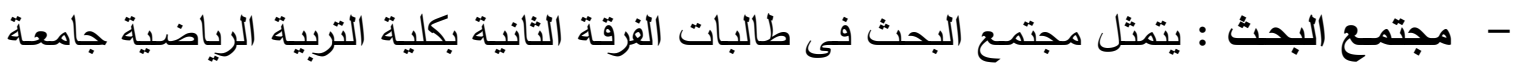
طنطا ، والمسجلات بالاتحاد المصرى لألعاب القوى للهواة وعددهم ( .0 ) طالبة .

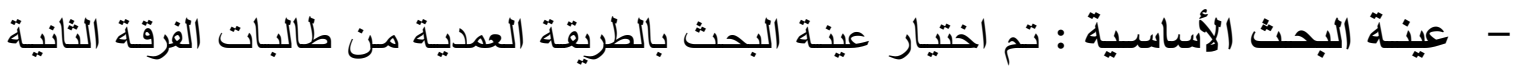

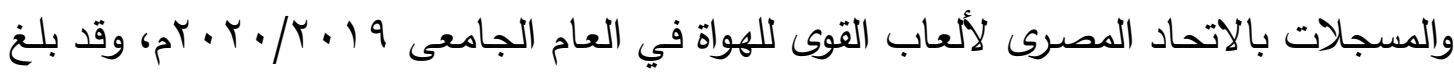




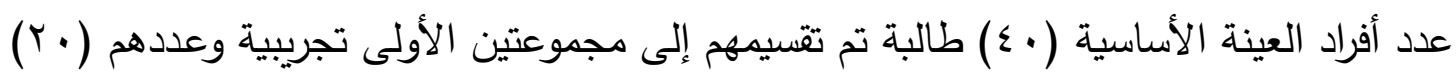

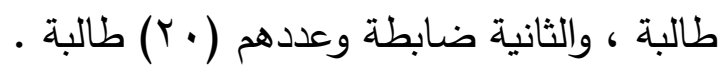

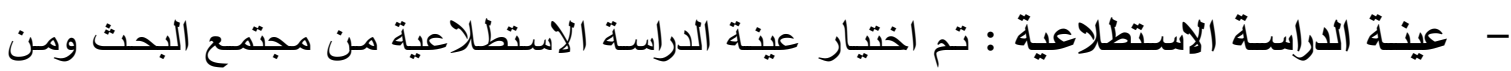

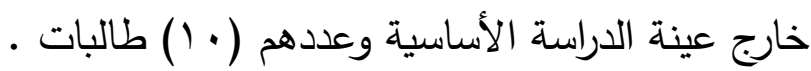
مجالات البحث :

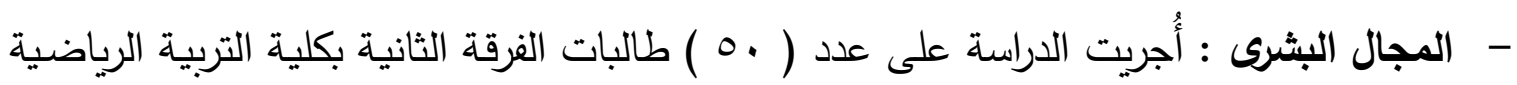

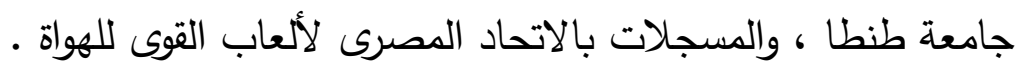

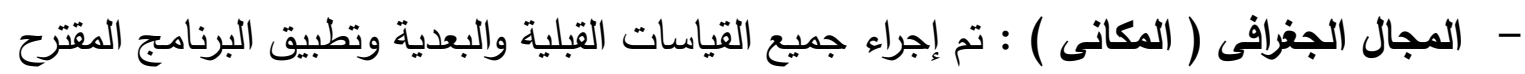

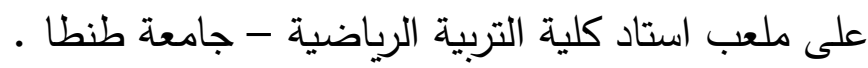

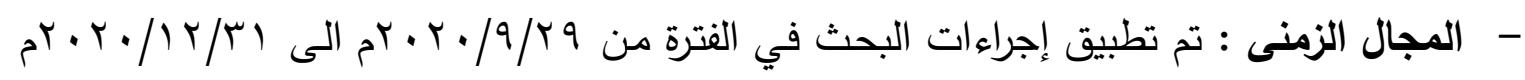

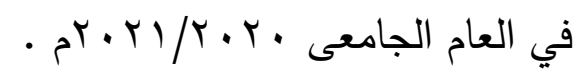
وسائل وأدوات جمع البيانات : = =

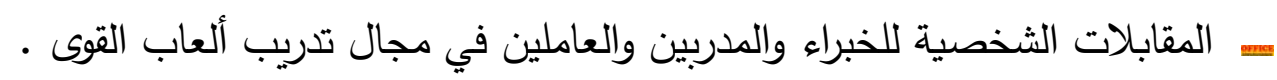

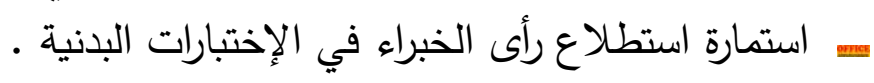

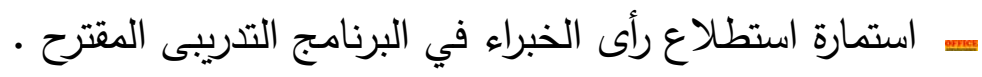

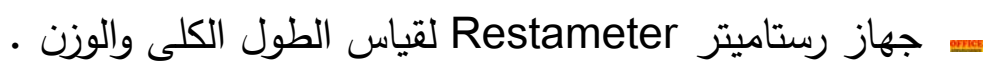

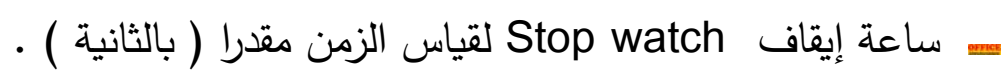

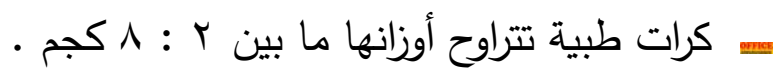

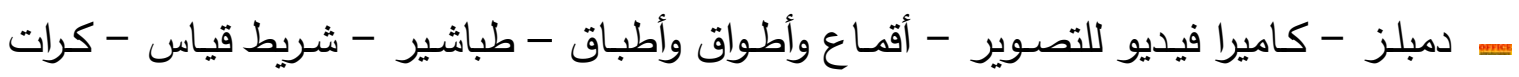

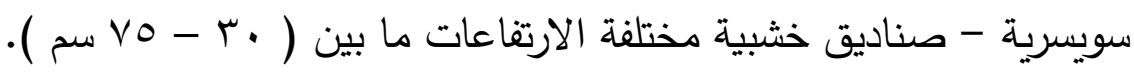
الاراسات الاستطلاعية : - الاراسة الاستطلاعية الأولى : الاستطات :

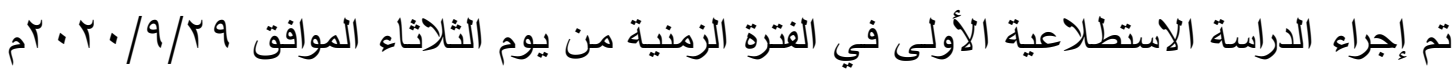

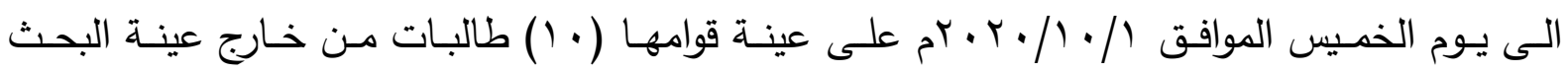

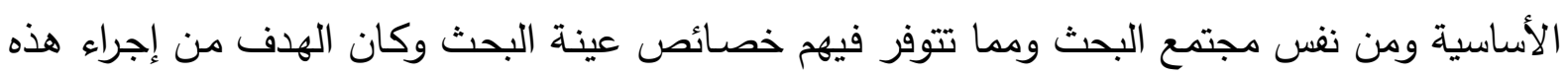

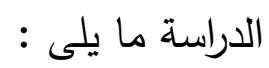
- التأكد من صلاحية الأجهزة والأدوات المستخدمة في القياس .

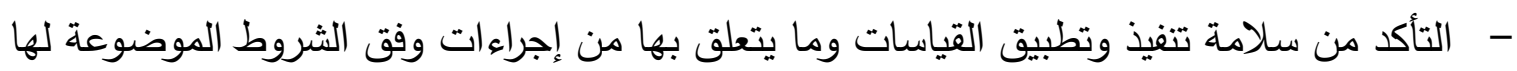

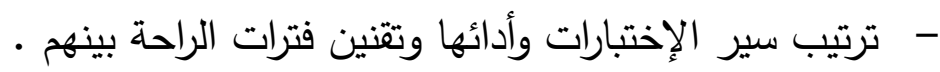

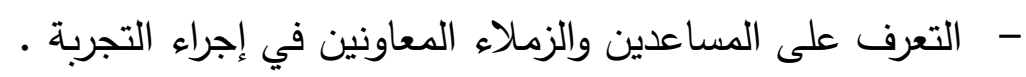
- مدى ملائمة الإختبارات لعينة البحث . 
- - تطبيق وحدات تدريبية للتأكد من صحة تقنين الأحمال التدريبية الخاصة بالتدريبات . - - اكتثاف الصعوبات التي قد تظهر أثناء إجراء التجربة الاستطلاعية والعمل على التغلب عليها

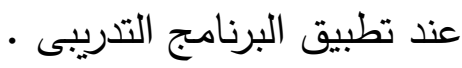
وكان من أهم نتائج الدراسة الاستطلاعية الأولى :

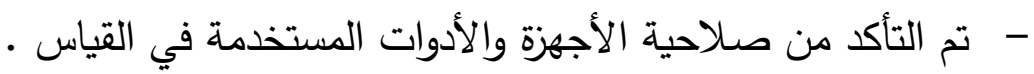

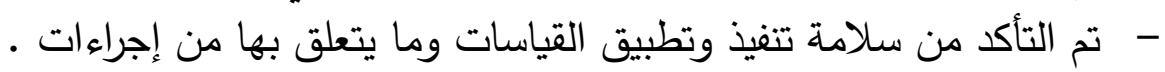

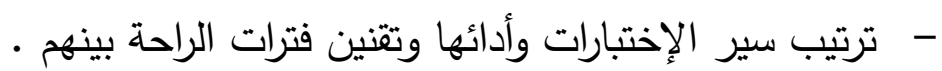

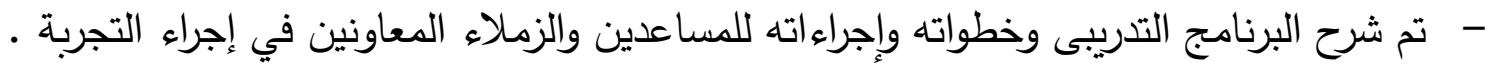

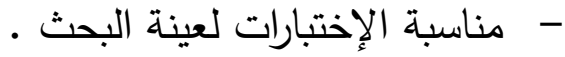

الاراسة الإستطلاعية الثانية :

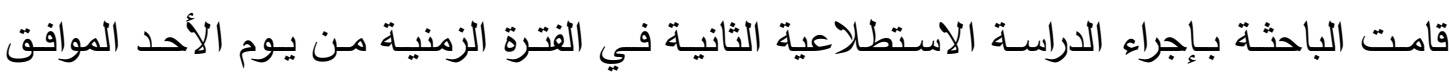

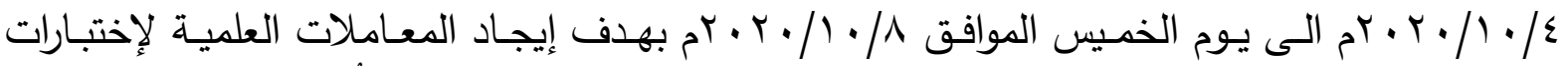

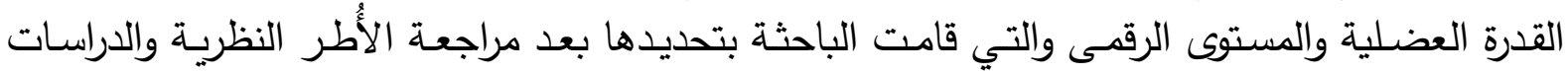

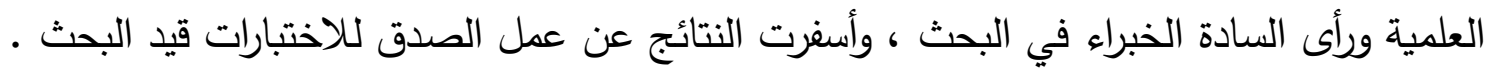

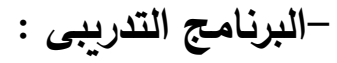

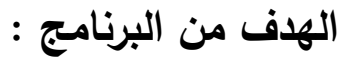
تطوير القدرة العضلية والمستوى الرقمى للاعبات قذف القرص عن طريق البرنامج التدريبى

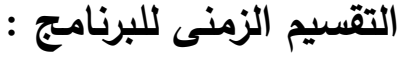

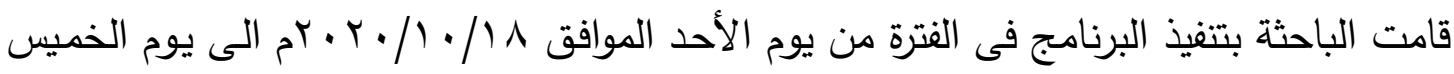

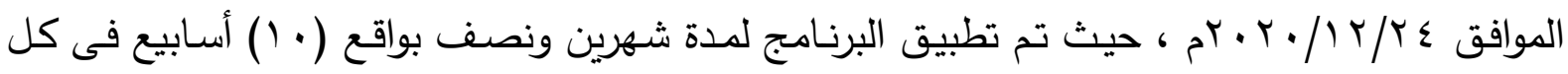

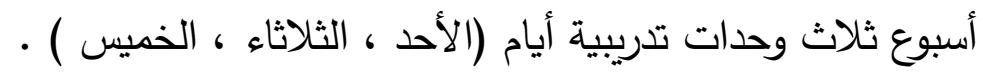

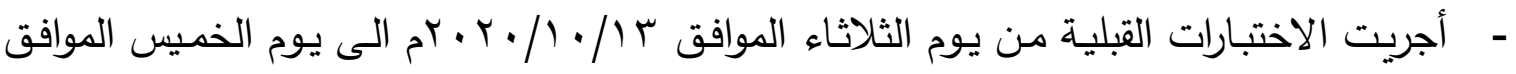

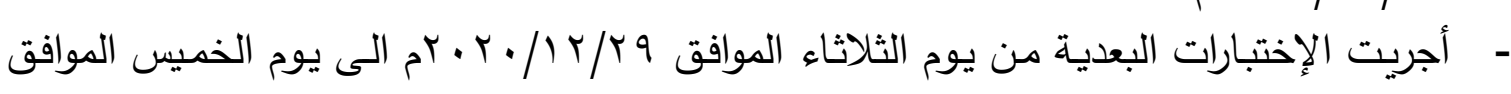

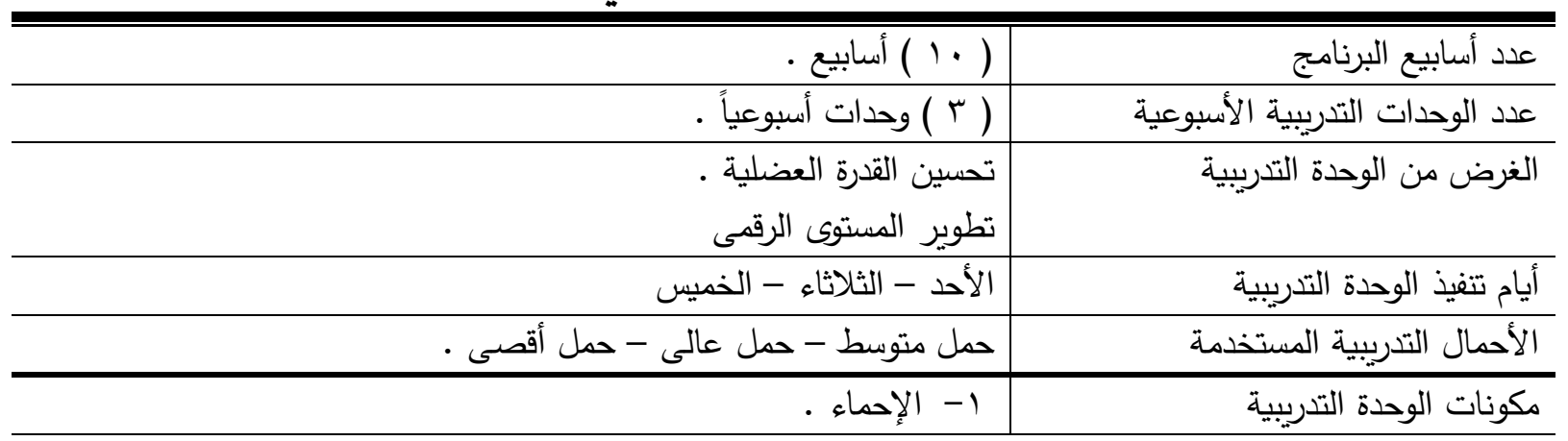




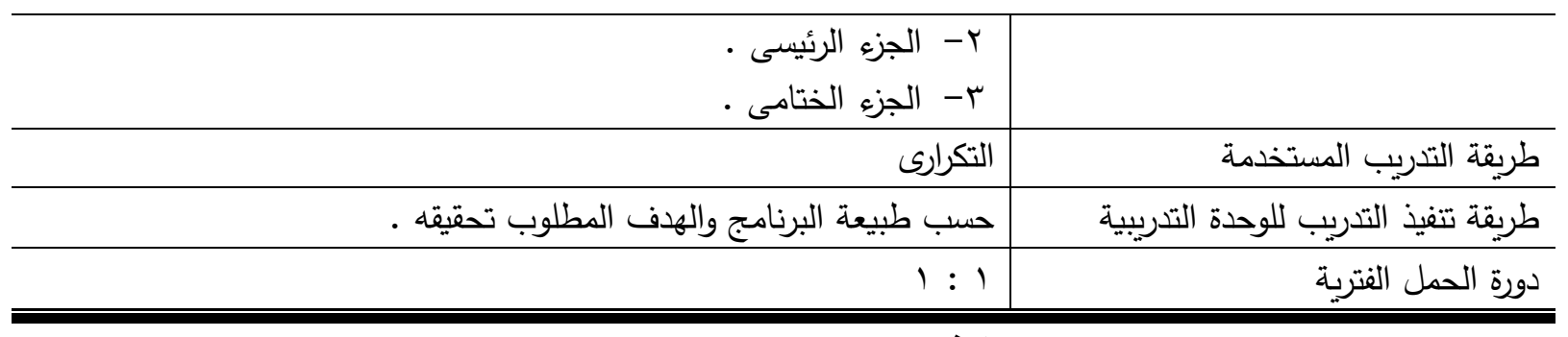

الاعتبارات التى يجب مراعاتها عند تنفيذ البرنامج :

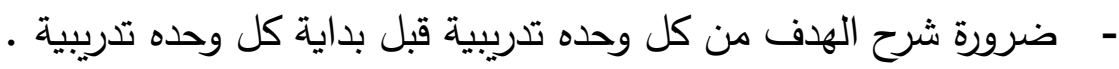

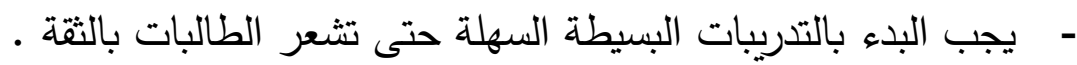

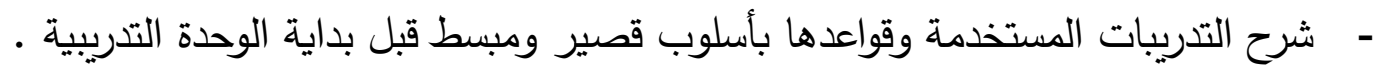

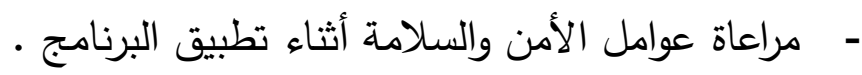

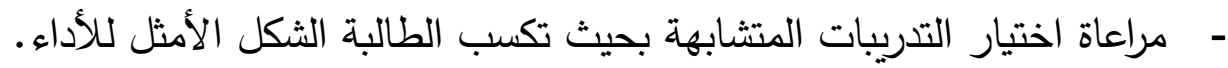

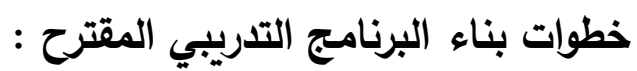

ا - الرجوع الى بعض المع المراجع التى توافرت لاءى الباحثة والبرامج التى وضعت لهذه المرحلة السنية

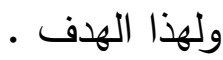

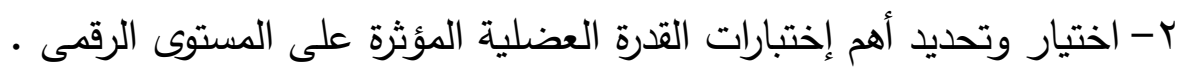

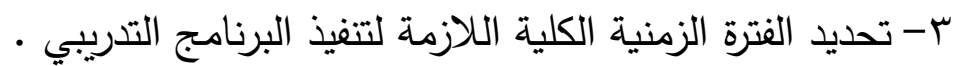

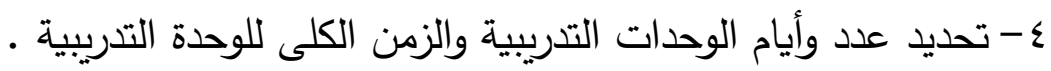

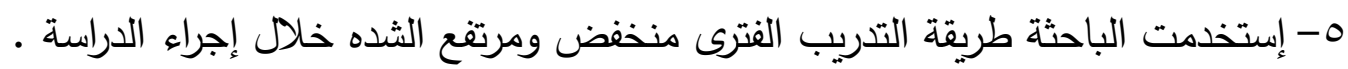

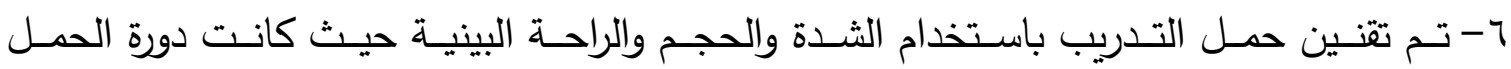

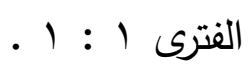

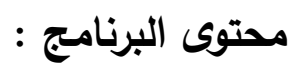

يحتوى البرنامج التدريبي المقترح على تدريبات القوة المتفجرة - والقوة المميزة بالسرعة - وتحمل

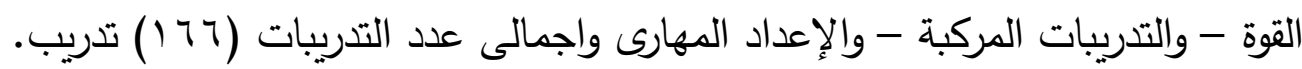

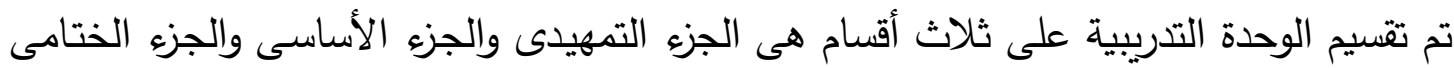

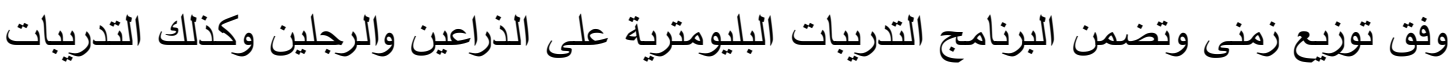

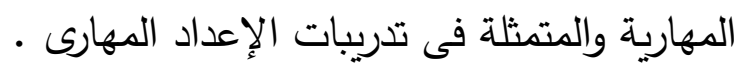




\section{جلول (r)}

توزيع درجات حمل التدريب خلال الأسابيع التي تضمنها البرنامج التدرببى للمجموعة التجريبية

\begin{tabular}{|c|c|c|c|c|c|c|c|c|c|c|}
\hline الألتبورع & الألنبع & الألسبون & الأسبلوع & اللسائسبوع & الألسبوع & الأسبوع ألبع & الألتبوع & الألتبوع & الأكبول & |لآنيقية \\
\hline & & & & & & & & & & اقعنى \\
\hline & & & & & & & & & & 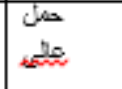 \\
\hline & & & & & & & & & & متوبط \\
\hline
\end{tabular}

يتضح من جدول (ب) والخاص بنسب توزيع درجات حمل التدريب خلال وحدات التدريب التى

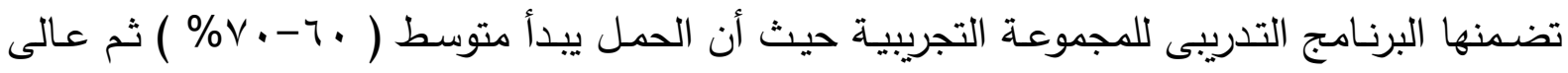

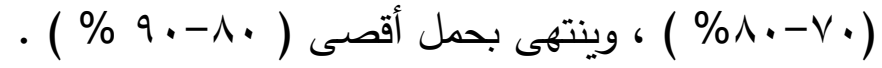

\section{جدول ( ) ( )}

نموذج لوحدة تدربيية للمجموعة التجريبية البرنامج التدريبى المقترح لتوريه لتمرينات الأثقال

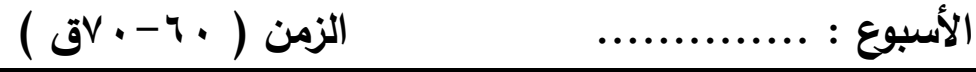

\begin{tabular}{|c|c|c|c|c|c|c|c|}
\hline المجموعات بين & المجموعات & التمرينات & تكرار & زأد ألمراء & الشدة الثد & مكونات الحمل & r \\
\hline ثا. & r & ث 7 . & $\wedge$ & ث & \multirow{5}{*}{ 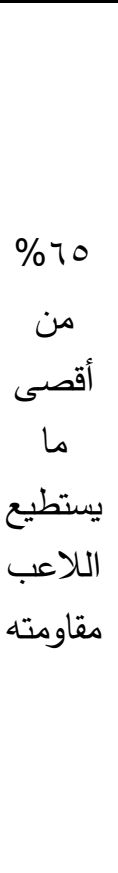 } & 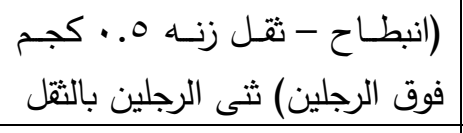 & 1 \\
\hline ثا. & r & . & $\wedge$ & 0 & & 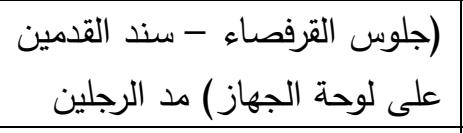 & $r$ \\
\hline ثا & r & ث & $\wedge$ & ث & & 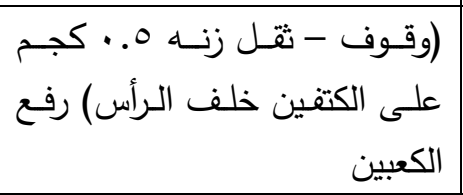 & $r$ \\
\hline ثا. & r & † . & $\wedge$ & 0 & & 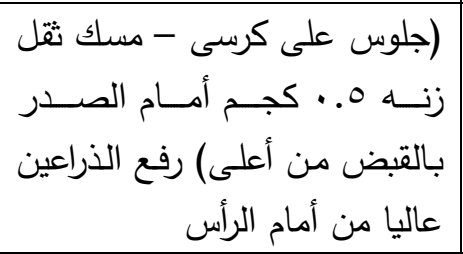 & $\varepsilon$ \\
\hline$\dot{~}$ & r & ث & $\wedge$ & ث & & 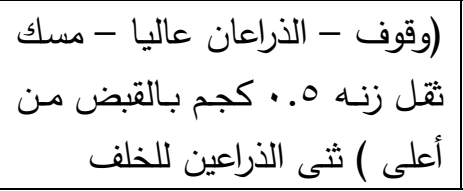 & 0 \\
\hline
\end{tabular}




$$
\begin{aligned}
& \begin{array}{r|r|r|r|r|r|r|r}
\hline & \\
\hline
\end{array} \\
& \text { القياس القبلى : }
\end{aligned}
$$

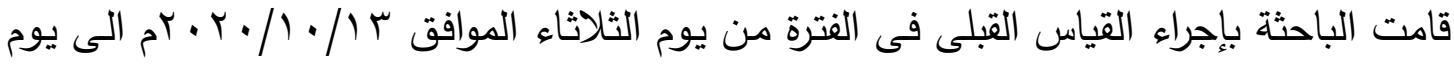

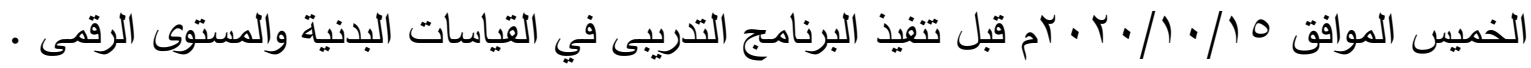

$$
\text { تطبيق البرنامج التتريبى : }
$$

قامت الباحثة بتطبيق البرنامج التدريبى المقترح على الطالبات (عينة البحث الأساسية) فى الفترة

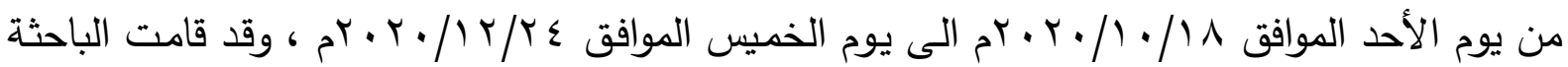

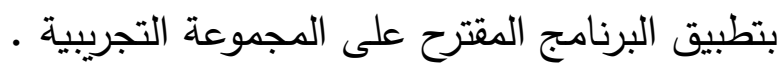

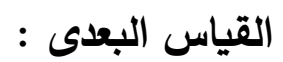

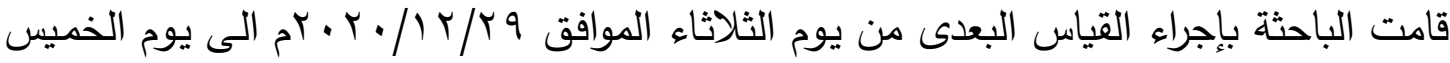

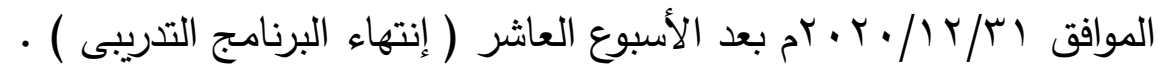

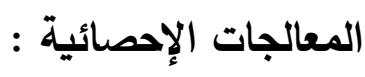

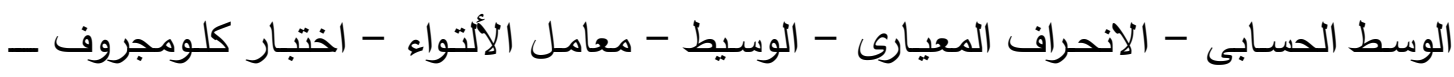

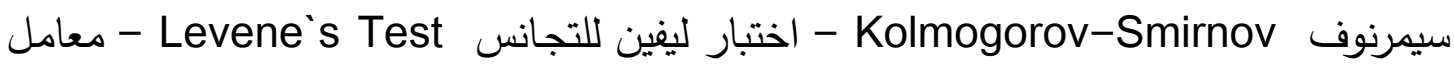
الارتباط (بيرسون) - نسبة التحسن - اختبار دلالة الفروق (ت) . 


\section{جدول ( ) ميطي}

عرض النتائج :

يوضح إحصاءات (ت) ودلالة الفروق بين متوسطي درجات القياس القبلى والبعدى للمجموعة (ل) التجريبية للمتغيرات قيد البحث دوبث

$r \cdot=\dot{ }$

\begin{tabular}{|c|c|c|c|c|c|c|}
\hline $\begin{array}{c}\text { Sig } \\
\text { P. Value } \\
(\cdot .0)\end{array}$ & قيمة (ت) & الحرية & المعياري ال المي & المنوسط & القياس & المتغير ات \\
\hline \multirow{2}{*}{$\because \cdots$} & \multirow{2}{*}{$M . V$} & \multirow{2}{*}{19} & 4.13 & ro.10 & قبلى & \multirow{2}{*}{ اختبار القدرة العضلية للرجلين } \\
\hline & & & 3.88 & $r 9.10$ & بعدى بع & \\
\hline \multirow{2}{*}{$\because \cdots$} & \multirow{2}{*}{$r 0.01$} & \multirow{2}{*}{19} & 0.04 & 1.01 & قبلى & \multirow{2}{*}{ اختبار القدرة العضلية للرجلين } \\
\hline & & & 0.04 & 1.07 & بعدى & \\
\hline \multirow{2}{*}{$\because \cdots$} & \multirow{2}{*}{18.41} & \multirow{2}{*}{19} & 2.51 & 11.70 & قبلى & \multirow{2}{*}{ اختبار تحمل القوة (ثنى } \\
\hline & & & 2.30 & $1 \leq .10$ & 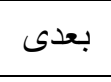 & \\
\hline \multirow{2}{*}{$\because \cdots$} & \multirow{2}{*}{18.63} & \multirow{2}{*}{19} & 0.33 & $r . v$. & قبلى & \multirow{2}{*}{ اختبار القدرة العضلية للذراعين } \\
\hline & & & 0.32 & $\varepsilon . \cdot r$ & بعدى & \\
\hline \multirow{2}{*}{$\because \cdots$} & \multirow{2}{*}{13.65} & \multirow{2}{*}{19} & 0.43 & V.Tr & قبلى & \multirow{2}{*}{ اختبار القدرة العضلية للذراعين } \\
\hline & & & 0.41 & $v .90$ & بعدى & \\
\hline \multirow{2}{*}{$\because \cdots$} & \multirow{2}{*}{17.37} & \multirow{2}{*}{19} & 0.37 & 7.7 & قبلى & \multirow{2}{*}{ اختبار القدرة العضلية للذراعين } \\
\hline & & & 0.35 & 7.19 & بعدى & \\
\hline \multirow{2}{*}{$\because \cdots$} & \multirow{2}{*}{15.68} & \multirow{2}{*}{19} & 0.32 & $0 . V V$ & قبلى & \multirow{2}{*}{ ختبار القدرة العضلية للذراعين } \\
\hline & & & 0.30 & 7.0 & بعدى & \\
\hline \multirow{2}{*}{$\because \cdots$} & \multirow{2}{*}{19.5.} & \multirow{2}{*}{19} & 3.34 & 10.00 & قبلى & \multirow{2}{*}{ اختبار تحمل القوة(صندوق } \\
\hline & & & 3.04 & rᄉ. 70 & بعدى & \\
\hline \multirow{2}{*}{$\because \cdots$} & \multirow{2}{*}{9.18} & \multirow{2}{*}{19} & 1.07 & $r \cdot . \cdot 9$ & قبلى & \multirow{2}{*}{ المستوى الرقمى } \\
\hline & & & 0.90 & $r \cdot .9 \leq$ & بعدى & \\
\hline
\end{tabular}

Y.قيمة (ت) الجدولية عند مستوى معنوية م. ...

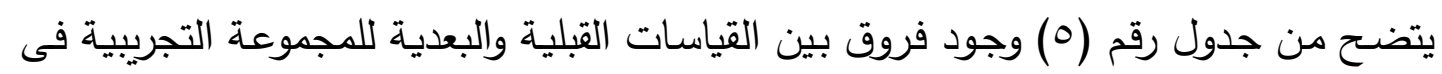

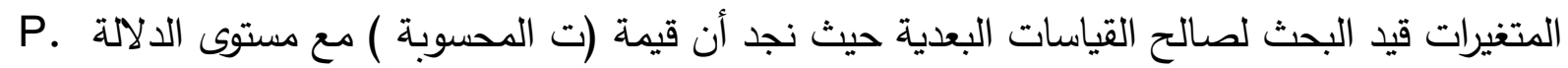

. ...0> Sig Value 


\section{جدول ( 14}

يوضح إحصاءات (ت) ودلالة الفروق بين متوسطي درجات القياس القبلى والبعدى للمجموعة الضابطة للمتغيرات قيد البحث

\begin{tabular}{|c|c|c|c|c|c|c|}
\hline $\begin{array}{c}\text { Sig } \\
\text { P. } \\
\text { Value } \\
(. .0)\end{array}$ & قيمة (ت) & دات الحرية & الانحر اف المعياري & المتوسط & القياس & المتغير ات \\
\hline \multirow{2}{*}{$\because \cdots$} & \multirow{2}{*}{ 1^.^o } & \multirow{2}{*}{19} & 4.18 & T. & قبلى & \multirow{2}{*}{ اختبار القدرة العضلية للرجلين } \\
\hline & & & 4.26 & $r \leqslant . Y$. & بعدى & \\
\hline \multirow{2}{*}{$\because \cdots$} & \multirow{2}{*}{ V.Y. } & \multirow{2}{*}{19} & 0.06 & 1.57 & قبلى & \multirow{2}{*}{ 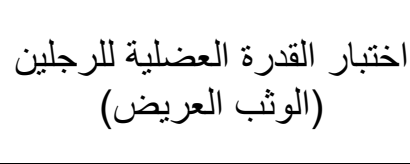 } \\
\hline & & & 0.07 & 1.0. & بعدى & \\
\hline \multirow{2}{*}{$\because \cdots$} & \multirow{2}{*}{13.30} & \multirow{2}{*}{19} & 1.74 & 9.9. & قبلى & \multirow{2}{*}{$\begin{array}{c}\text { اختبار تحمل القوة (ثنى الذين) } \\
\text { الذر اعين) }\end{array}$} \\
\hline & & & 1.72 & 11.7 & بعدى & \\
\hline \multirow{2}{*}{$\because \cdots$} & \multirow{2}{*}{11.00} & \multirow{2}{*}{19} & 0.28 & ס r. & قبلى & \multirow{2}{*}{ اختبار القدرة العضلية } \\
\hline & & & 0.29 & r.or & بعدى & \\
\hline \multirow{2}{*}{$\because \cdots$} & \multirow{2}{*}{14.13} & \multirow{2}{*}{19} & 0.36 & v.. & قبلى & \multirow{2}{*}{ اختبار القدرة العضلية } \\
\hline & & & 0.35 & V.r & بعدى & \\
\hline \multirow{2}{*}{$\because \cdots$} & \multirow{2}{*}{15.75} & \multirow{2}{*}{19} & 0.40 & 0.10 & قبلى & \multirow{2}{*}{ اختبار القدرة العضلية } \\
\hline & & & 0.37 & $0.9 V$ & بعدى & \\
\hline \multirow{2}{*}{$\because \cdots$} & \multirow{2}{*}{17.08} & \multirow{2}{*}{19} & 0.44 & ר ט & قبلى & \multirow{2}{*}{ اختبار القدرة العضلية } \\
\hline & & & 0.44 & 0.07 & بعدى & \\
\hline \multirow{2}{*}{$\because \cdots$} & \multirow{2}{*}{ 10.TV } & \multirow{2}{*}{19} & 2.39 & rᄉ. 70 & قبلى & \multirow{2}{*}{$\begin{array}{c}\text { اختبار تحمل القوة(صندوق } \\
\text { الخطو) }\end{array}$} \\
\hline & & & 2.28 & $r . .00$ & 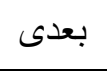 & \\
\hline \multirow{2}{*}{$\because \cdots$} & \multirow{2}{*}{12.05} & \multirow{2}{*}{19} & 1.36 & rی.r & قبلى & \multirow{2}{*}{ المستوى الرقمى } \\
\hline & & & 1.32 & rA. 79 & بعدى & \\
\hline
\end{tabular}

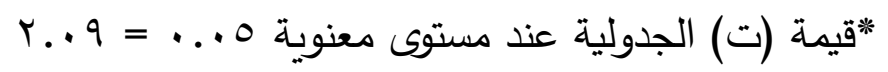

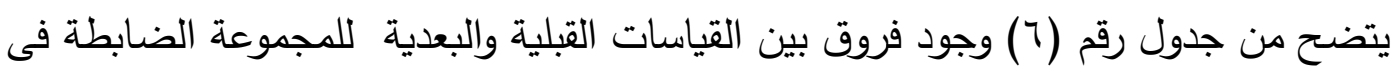

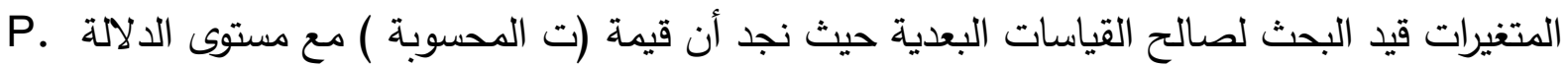




\section{جدول (v ) ج (v)}

يوضح إحصاءات (ت) ودلالة الفروق بين متوسطي درجات عينة المجموعتين التجريبية والضابطة في القياسات البعدية للمتفيرات قيد البحث

\begin{tabular}{|c|c|c|c|c|c|c|}
\hline $\begin{array}{c}\text { Sig } \\
\text { P. Value } \\
(\cdot .0)\end{array}$ & قيمة (ت) & المتوسطن & المعياري ال المر اف & المتوسط & المجمو عة & المتغيرات \\
\hline \multirow{2}{*}{$\because \cdots$} & \multirow{2}{*}{ r.Ar } & \multirow{2}{*}{$\leqslant .90$} & 3.88 & rq.10 & التجريبية & \multirow{2}{*}{ للرجلين (الوثب العمودى العضلية } \\
\hline & & & 4.26 & $r \varepsilon . r$. & الضابطة & \\
\hline \multirow{2}{*}{$\because \cdots$} & \multirow{2}{*}{ r.9r } & \multirow{2}{*}{$\because .7$} & 0.04 & 1.07 & التجرييية & \multirow{2}{*}{ للارجلين (الوثب العريضل العضلية } \\
\hline & & & 0.07 & 1.0. & الضابطة & \\
\hline \multirow{2}{*}{$\because \cdots$} & \multirow{2}{*}{ r.97 } & \multirow{2}{*}{$r .00$} & 2.30 & $1 \leq .10$ & التجريبية & \multirow{2}{*}{$\begin{array}{c}\text { اختبار تحمل القوة (ثنى الذين) } \\
\text { الذراعين }\end{array}$} \\
\hline & & & 1.72 & 11.7 & الضـابطة & \\
\hline \multirow{2}{*}{$\because \cdots$} & \multirow{2}{*}{$\varepsilon .91$} & \multirow{2}{*}{$\cdot .29$} & 0.32 & $\varepsilon . r$ & التجرييية & \multirow{2}{*}{ اختبار القدرة العضلية } \\
\hline & & & 0.29 & r.or & الضابطة & \\
\hline \multirow{2}{*}{$\because \cdots$} & \multirow{2}{*}{5.19} & \multirow{2}{*}{0.63} & 0.41 & $v .90$ & التجريبية & \multirow{2}{*}{ اختبار القدرة العضلية } \\
\hline & & & 0.35 & V.TY & الضابطة & \\
\hline \multirow{2}{*}{$\because \cdots$} & \multirow{2}{*}{7.99} & \multirow{2}{*}{0.92} & 0.35 & $7 . \wedge 9$ & التجريبية & \multirow{2}{*}{ اختبار القدرة العضلية } \\
\hline & & & 0.37 & $0.9 V$ & الضابطة & \\
\hline \multirow{2}{*}{$\because \cdots$} & \multirow{2}{*}{4.10} & \multirow{2}{*}{0.49} & 0.30 & 7.0 & التجريبية & \multirow{2}{*}{ اختبار القدرة العضلية } \\
\hline & & & 0.44 & 0.07 & الضابطة & \\
\hline \multirow{2}{*}{$\because \cdots$} & \multirow{2}{*}{9.51} & \multirow{2}{*}{8.10} & 3.04 & rی.70 & التجريبية & \multirow{2}{*}{$\begin{array}{c}\text { اختبار تحمل القوة(صندوق } \\
\text { الخطو) }\end{array}$} \\
\hline & & & 2.28 & $r \cdot .00$ & الضابطة & \\
\hline \multirow[b]{2}{*}{$\because \cdots$} & \multirow[b]{2}{*}{6.27} & \multirow[b]{2}{*}{2.25} & 0.90 & $r \cdot .9 \varepsilon$ & التجربيية & \multirow[b]{2}{*}{ المستوى الرقمى } \\
\hline & & & 1.32 & $r \wedge .79$ & الضـابطة & \\
\hline
\end{tabular}

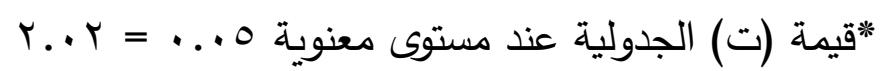

يوضـح جدول (V) وجود فروق ذات دلالـة احصـائية بين القياسـات البعديـة لدى المجموعتين

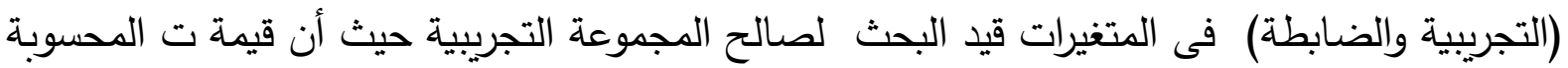
أكبر من قيمة ت الجدولية عند مستوى معنوية ه .... 


\section{جدول ( 1 )}

يوضح نسبة التحسن بين التطبيق القبلى والبعدى للمجموعة التجريبية للمتغيرات قيد البحث

$r \cdot=\dot{0}$

\begin{tabular}{|c|c|c|c|c|c|}
\hline نسبة التحسن & قيمة (ت) & الحرية & المتوسط & 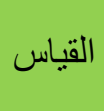 & المتغير ات \\
\hline \multirow{2}{*}{$\% q . r}$. & \multirow{2}{*}{$1 T . V$} & \multirow{2}{*}{19} & ro.10 & 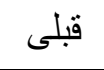 & \multirow{2}{*}{ 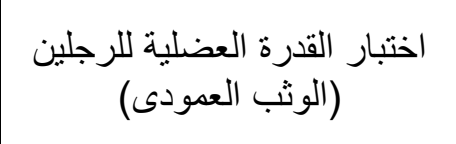 } \\
\hline & & & $r 9.10$ & 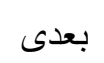 & \\
\hline \multirow[t]{2}{*}{$\%$ \%.r. } & \multirow{2}{*}{ ro.01 } & \multirow{2}{*}{19} & 1.01 & 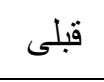 & \multirow{2}{*}{ 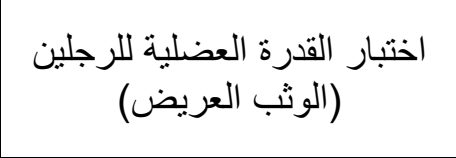 } \\
\hline & & & 1.07 & 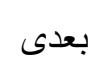 & \\
\hline \multirow{2}{*}{$\%$ Y.$\leq 0$} & \multirow{2}{*}{18.41} & \multirow{2}{*}{19} & 11.70 & 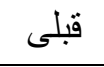 & \multirow{2}{*}{ اختبار تحمل القوة (ثىى الذر اعين) } \\
\hline & & & $1 \leq .10$ & بعدى & \\
\hline \multirow[t]{2}{*}{$\% \wedge .7 \varepsilon$} & \multirow{2}{*}{18.63} & \multirow{2}{*}{19} & r.v. & قبلى & \multirow{2}{*}{ اختبار القدرة العضلية للذراعين ا } \\
\hline & & & $\varepsilon . r$ & 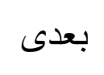 & \\
\hline \multirow{2}{*}{$\% \leqslant . \mu T$} & \multirow{2}{*}{13.65} & \multirow{2}{*}{19} & V.Tt & 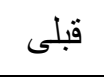 & \multirow{2}{*}{ اختبار القدرة العضلية للذراعين ب } \\
\hline & & & $V .90$ & 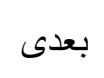 & \\
\hline \multirow[t]{2}{*}{$\% \leqslant . \Gamma q$} & \multirow{2}{*}{17.37} & \multirow{2}{*}{19} & 7.7. & 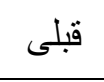 & \multirow{2}{*}{ اختبار القدرة العضلية للذراعين r } \\
\hline & & & 7.19 & 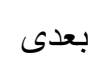 & \\
\hline \multirow[t]{2}{*}{$\% \leqslant .10$} & \multirow{2}{*}{15.68} & \multirow{2}{*}{19} & $0 . V V$ & 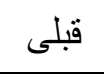 & \multirow{2}{*}{ اختبار القدرة العضلية للذراعين ـ } \\
\hline & & & $7 . .0$ & بعدى بع & \\
\hline \multirow{2}{*}{$\% \wedge . \vee r$} & \multirow{2}{*}{$19 . r$} & \multirow{2}{*}{19} & ro.00 & 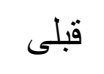 & \multirow{2}{*}{ ختبار تحمل القوة(صندوق الخطو) } \\
\hline & & & rA. 70 & 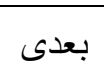 & \\
\hline \multirow[t]{2}{*}{$\%$ \%.Ar } & \multirow{2}{*}{9.18} & \multirow{2}{*}{19} & $r \cdot .9$ & 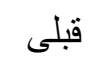 & \multirow{2}{*}{ المستوى الرقمى } \\
\hline & & & $r \cdot .9 \varepsilon$ & 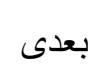 & \\
\hline
\end{tabular}

تثير نتائج جدول (^) نسبة التحسن بين القياس (القبلي/البعدى) للمجموعة التجريبية وتراوحت

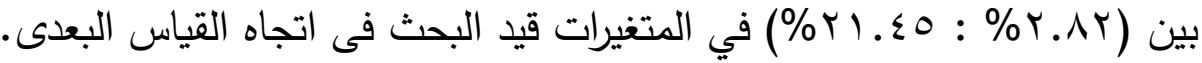




\section{جدول (9)}

يوضح نسبة التحسن بين التطبيق القبلى والبعدى للمجموعة الضابطة للمتغيرات قيد البحث $r_{0}=\dot{0}$

\begin{tabular}{|c|c|c|c|c|c|}
\hline نسبة التحسن & قيمة (ت) & الدرجية & 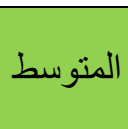 & 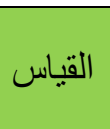 & المتغير ات \\
\hline \multirow{2}{*}{$\% \wedge . .0$} & \multirow{2}{*}{11.10} & \multirow{2}{*}{19} & $r 1.70$ & قبلى قى & \multirow{2}{*}{ 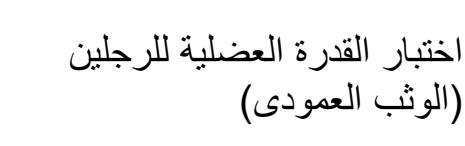 } \\
\hline & & & $r \varepsilon . r$. & 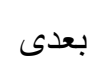 & \\
\hline \multirow{2}{*}{$\% r \cdot v r$} & \multirow{2}{*}{ V.r. } & \multirow{2}{*}{19} & 1.87 & 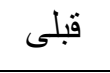 & \multirow{2}{*}{ (الوثبار القريضة العضلية للرجلين } \\
\hline & & & 1.0 & بعدى & \\
\hline \multirow{2}{*}{$\%$ IV.IV } & \multirow{2}{*}{13.30} & \multirow{2}{*}{19} & 9.9. & قبلى ق & \multirow{2}{*}{ اختبار تحمل القوة (ثىى الذراعين) } \\
\hline & & & 11.7. & بعدى & \\
\hline \multirow{2}{*}{$\% \wedge .{ }^{\top 1}$} & \multirow{2}{*}{11.00} & \multirow{2}{*}{19} & r.ro & 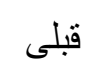 & \multirow{2}{*}{ ختبار القدرة العضلية للذراعين } \\
\hline & & & r.or & بعدى & \\
\hline \multirow{2}{*}{$\% r . \cdot 9$} & \multirow{2}{*}{14.13} & \multirow{2}{*}{19} & v.l. & قبلى قى & \multirow{2}{*}{ ختبار القدرة العضلية للأراعين † } \\
\hline & & & P.Mr & بعدى & \\
\hline \multirow{2}{*}{$\% r . \wedge r$} & \multirow{2}{*}{15.75} & \multirow{2}{*}{19} & $0 . V_{0}$ & 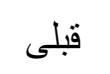 & \multirow{2}{*}{ اختبار القدرة العضلية للذر اعين r } \\
\hline & & & $0.9 \mathrm{~V}$ & بعدى & \\
\hline \multirow{2}{*}{$\% r . V r$} & \multirow{2}{*}{17.08} & \multirow{2}{*}{19} & 0.44 & 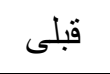 & \multirow{2}{*}{ اختبار القدرة العضلية للذراعين ؛ } \\
\hline & & & 0.07 & بعدى & \\
\hline \multirow{2}{*}{$\% 4.7 \pi$} & \multirow{2}{*}{$10 . r v$} & \multirow{2}{*}{19} & Y1. 70 & 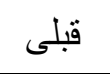 & \multirow{2}{*}{ اختبار تحمل القوة(صندوق الخطو) } \\
\hline & & & $r \cdot .00$ & 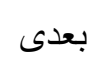 & \\
\hline \multirow[b]{2}{*}{$\% 1 . r v$} & \multirow[b]{2}{*}{12.05} & \multirow[b]{2}{*}{19} & YA.rT & قبلى قى & \multirow{2}{*}{ المستوى الرقمى } \\
\hline & & & YA. 79 & بعدى & \\
\hline
\end{tabular}

تثير نتائج جدول (9) نسبة التحسن بين القياس (القبلي/البعدى) للمجموعة الضـابطة وتراوحت

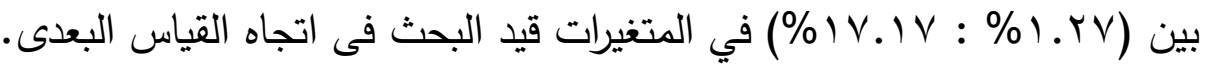
مناقشة النتائج : عابن

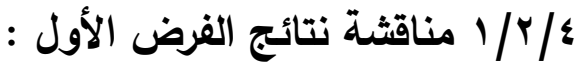
والذى ينص على (توجد فروق ذات دلالتة إحصائية بين متوسطى القياسين القبلى والبعدى الاولى

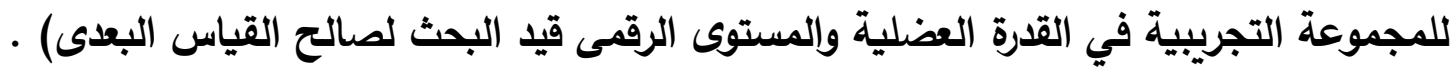


يتضـح من جدول رقم (0) وجود فروق بين القياسـات القبلية والبعديـة للمجموعة التجريبية فى

P. المتغيرات قيد البحث لصالح القياسات البعدية حيث نجد أن قيمة (ت المحسوبة ) مع مستوى الدلالة . ... > Sig Value

ويتضح أن المتوسط الحسابى لاختبار القدرة العضلية للرجلين (الوثب العمودى) بلـغ في القياس القبلى (10.0 ب) ، وفى القياس البعدى (0 1.9\%) ، والمتوسط الحسابى لاختبار القدرة العضلية للرجلين (الوثب العريض) بلغ في القياس القبلى (1.01. ) ، وفى القياس البعدى (1.07. ) ، والمتوسط الحسابى

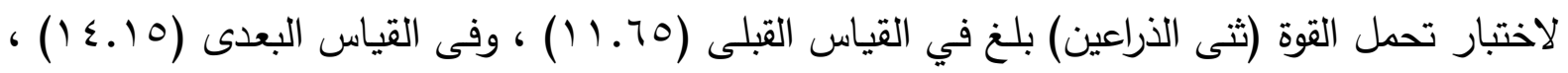
والمتوسط الحسابى لاختبار القدرة العضلية للذراعين إإختبار دفع كرة طبية ( س كجم ) باليدين من

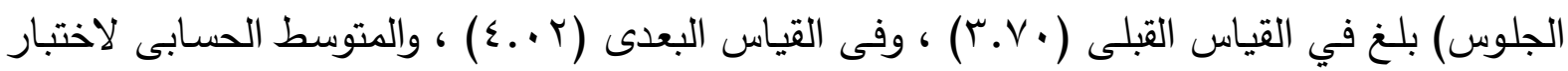

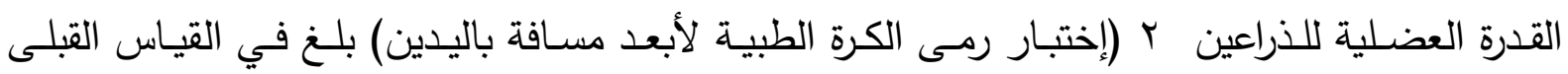

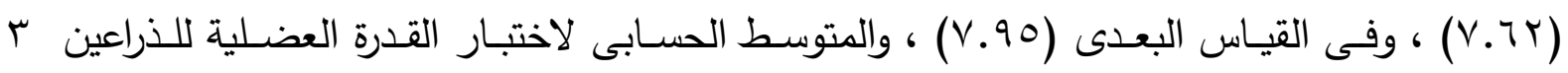

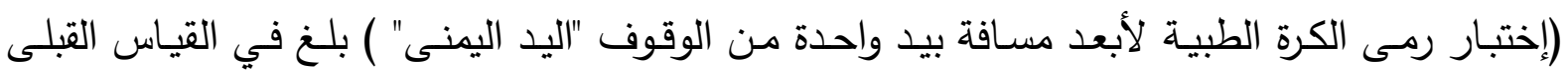

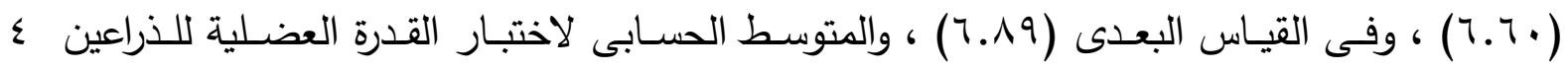
(إختبار رمسى الكرة الطبية لأبعد مسـافة بيد واحدة من الوقوف "اليد اليسرى" ) بلـغ في القياس القبلى لإلى

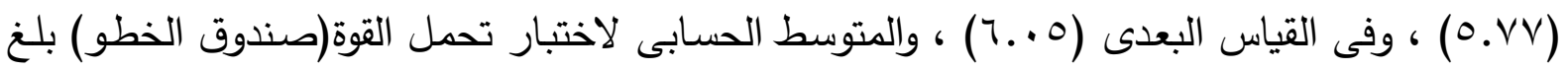

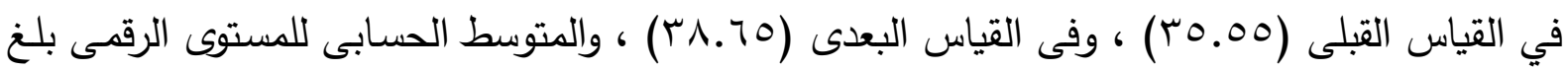

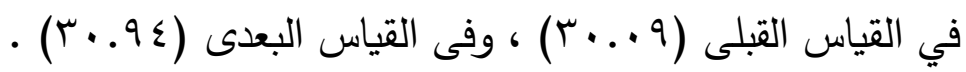
ويتضح من جدول (^) نسبة التحسن بين القياس (القبلي/البعدى) للمجموعة التجريبية وتراوحت

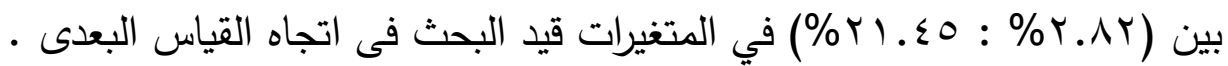

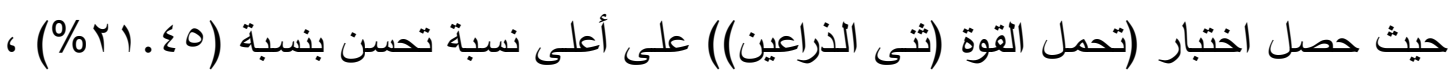
ويليه اختبار القدرة العضلية للرجلين (الوثب العدودى) بنسبة تحسن بلغت ( • .9\%) ، ويليه اختبار

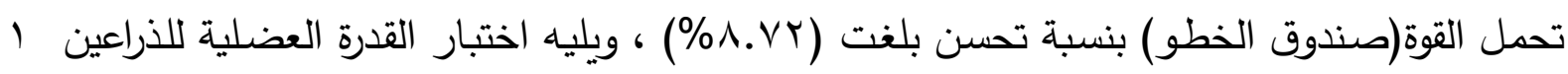

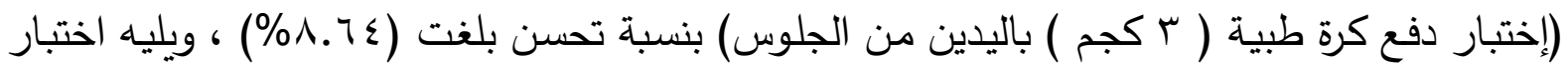
القدرة العضلية للذراعين (إختبار رمى الكرة الطبية لأبعد مسافة بيد واحدة من الوقوف "اليد اليسرى" ) بنسبة تحسن بلغت (0^. §\%) ، ويليه اختبار القدرة العضلية للذراعين ب (إختبار رمسى الكرة الطبية لأبعد مسافة بيد واحدة من الوقوف "اليد اليمنى" ) بنسبة تحسن بلغت (9 ؟ـ؛\%) ، ولييه اختبار القدرة العضلية للذراعين (إختبار رمى الكرة الطبية لأبعد مسافة باليدين) بنسبة تحسن بلغت (بس. ؟ \%) ، ويليه اختبار القدرة العضلية للرجلين (الوثب العريض) بنسبة تحسن بلغت (اس.ب\%) ، ويليه اختبار

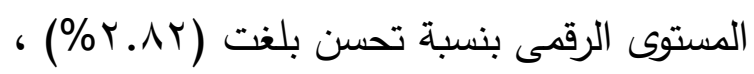


وترجع الباحثة سبب وجود تلك الفروق إلى أن تطبيق أسلوب التدريب البليومترى داخل البرنامج

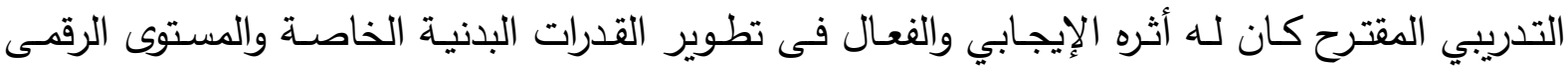

وتدل هذه الفروق على أن التدريب البليومترى له تأثير هام فى تتمية القدرة العضلية للذراعين

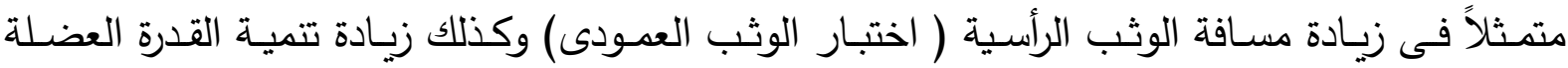

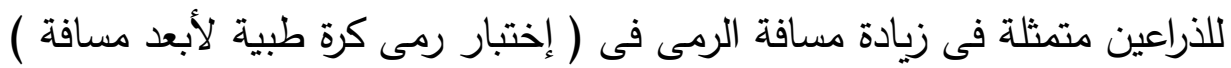

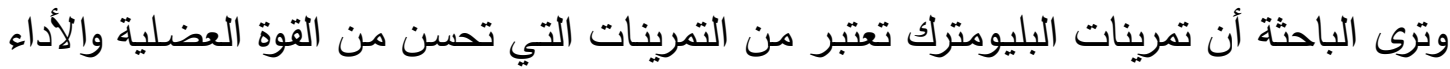

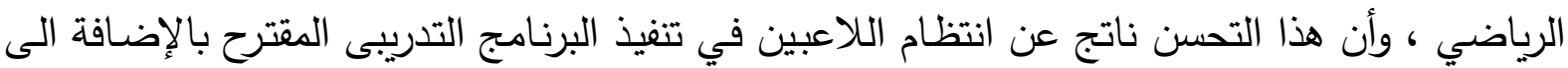
مبدأ الإستمرار والتدرج في التدريب كأحد المبادئ الأساسية في تتمية تحمل التفام القدرة العضلية .

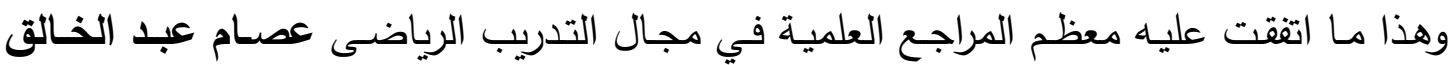

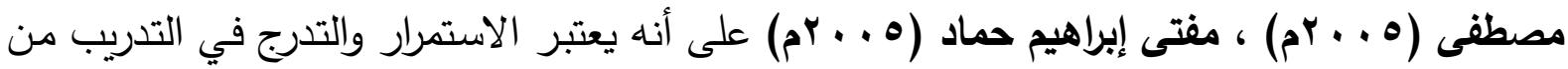

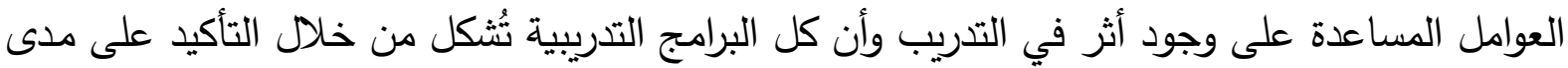

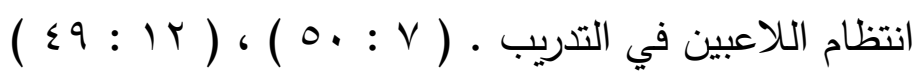

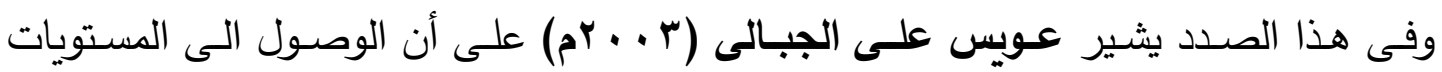

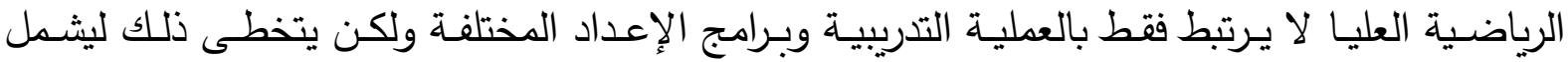

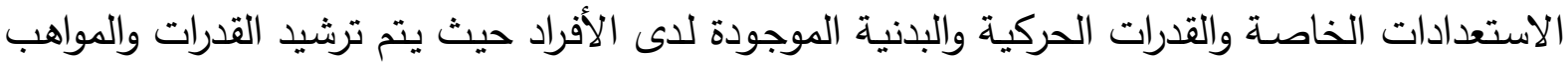
الخاصة من خلال توجيهها والعناية بها حتى يمكن تحقيق الأهداف العامة من عملية الممارسة والوصول الإني

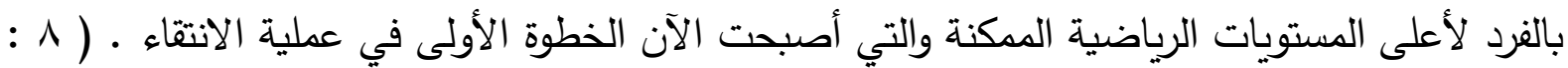

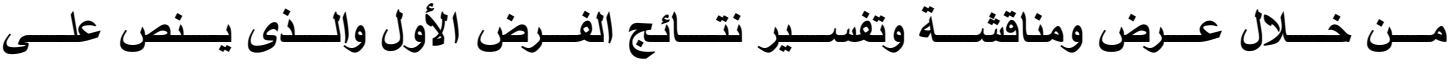

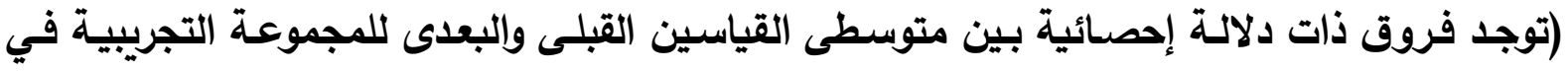

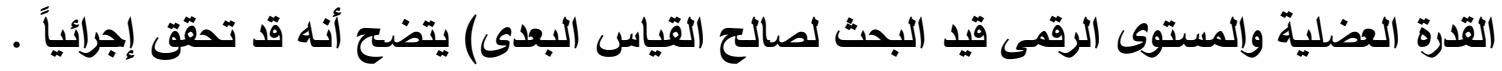

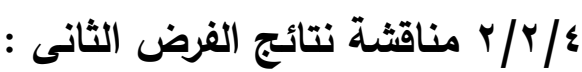
والذى ينص على (توجد فروق ذات دلالة إحصائية بين متوسطى القياسين القبلى والبعدى القيأي

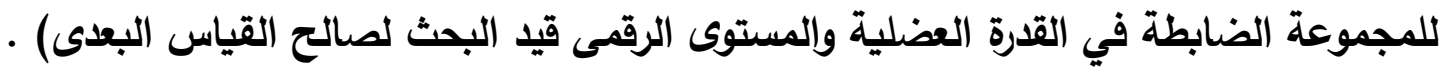

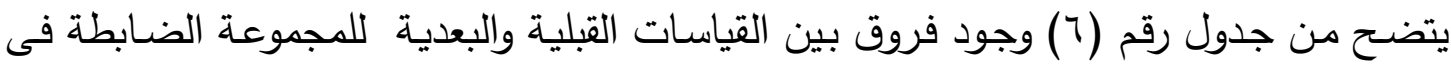

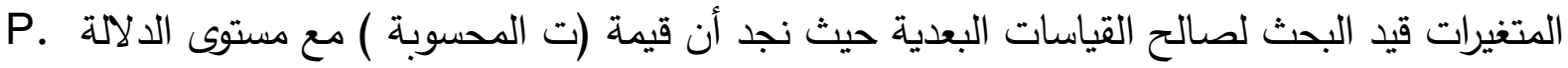
. ...0> Sig Value

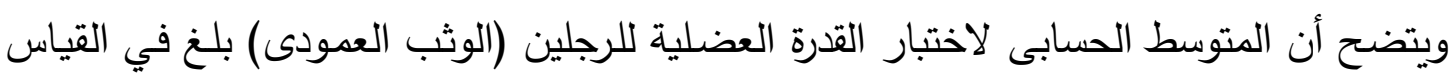

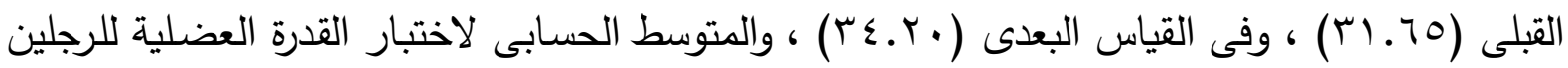

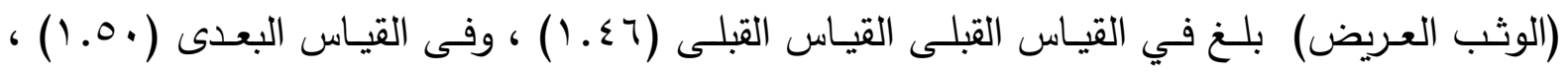

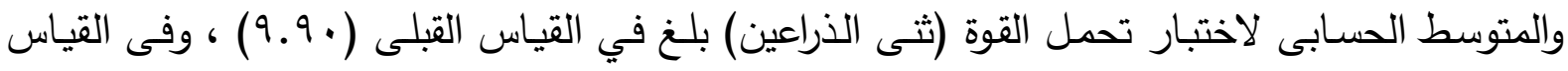

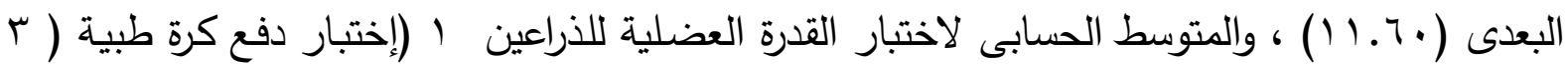




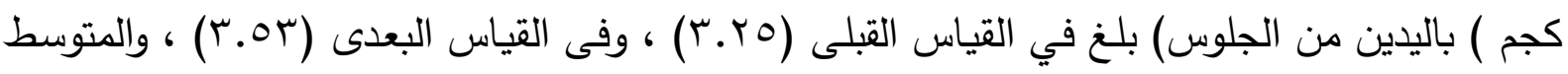

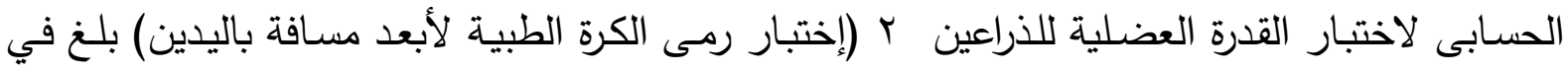

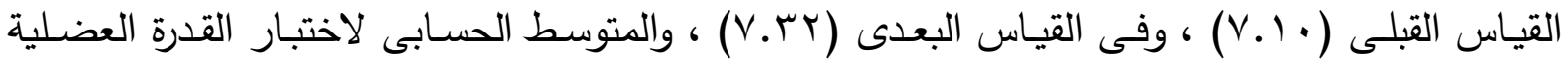

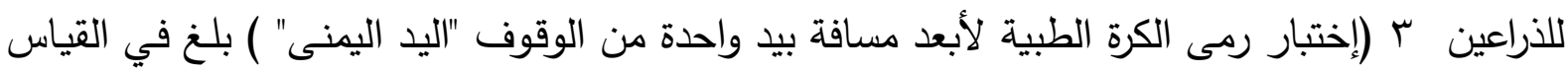

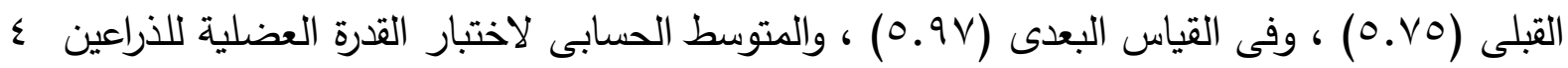

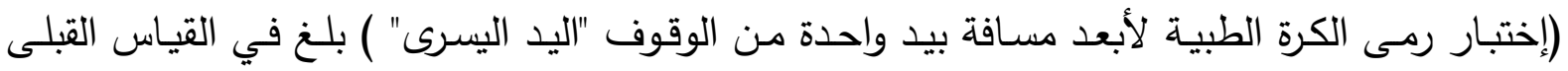

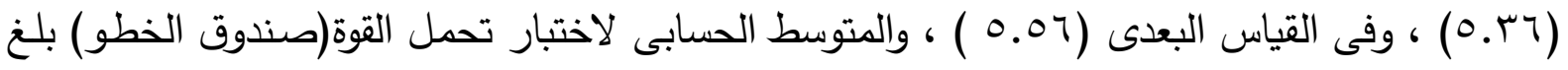

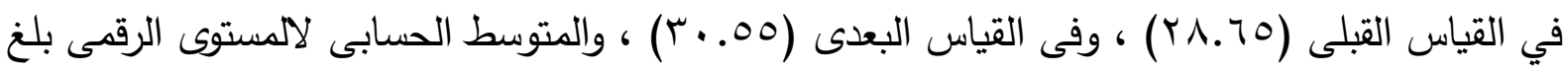

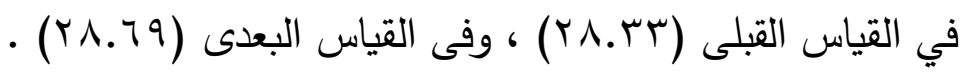

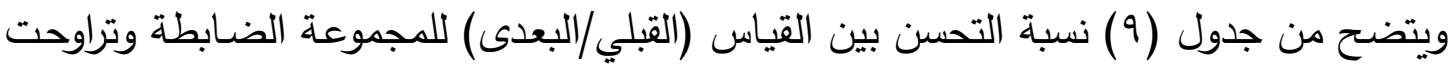

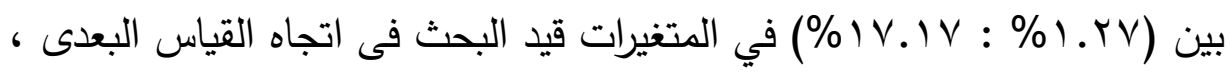

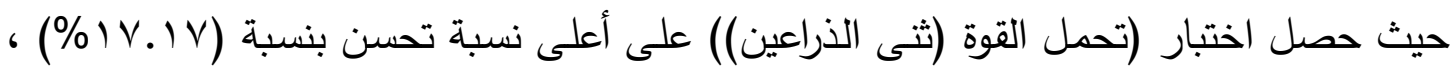

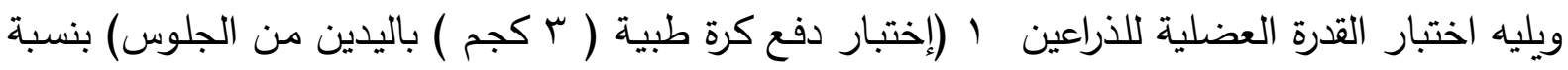

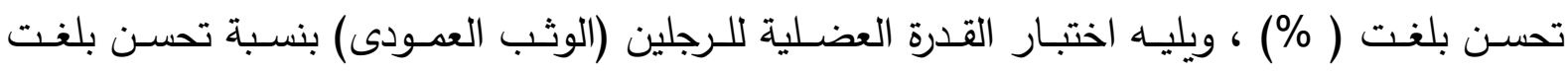

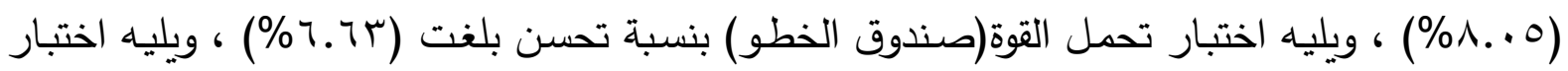

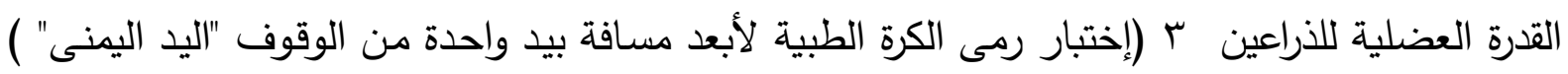

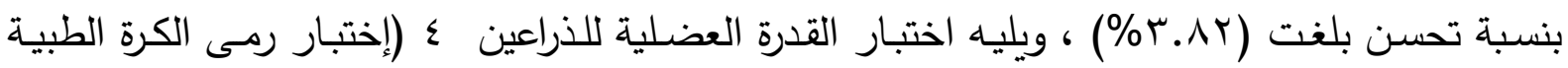

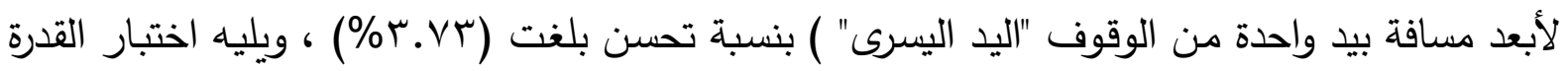

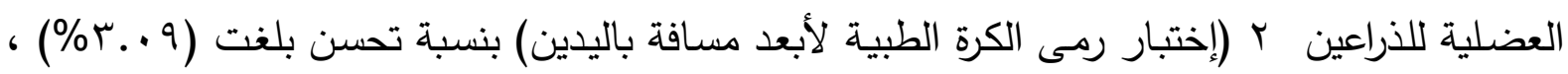

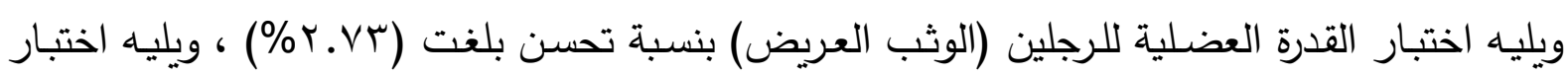

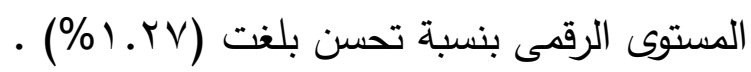

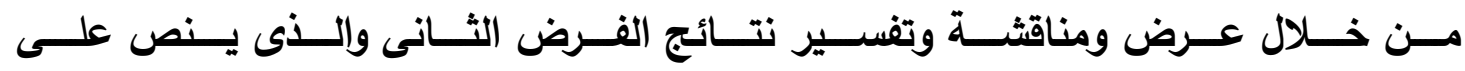

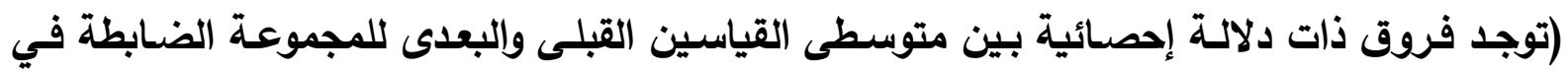

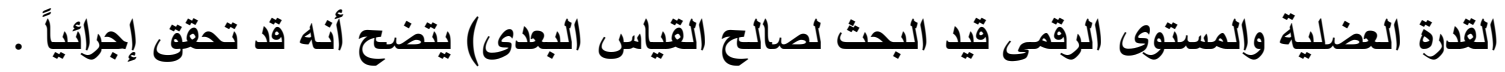

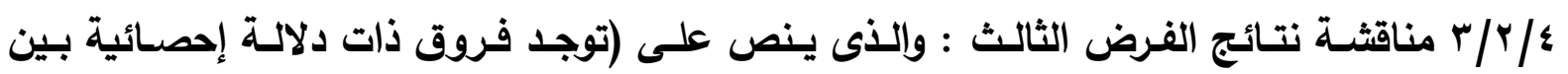

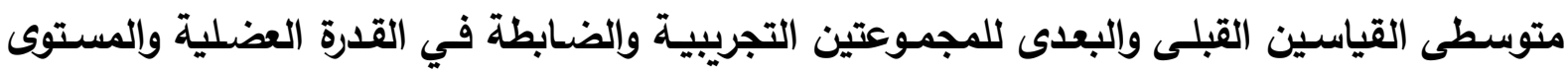
الرقمى قيد البحث لصالح المجموعة التجريبية) .

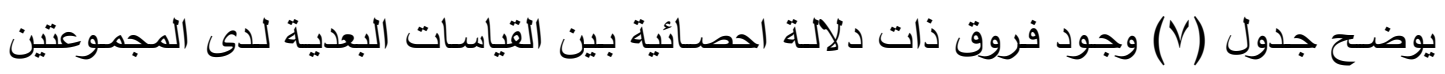

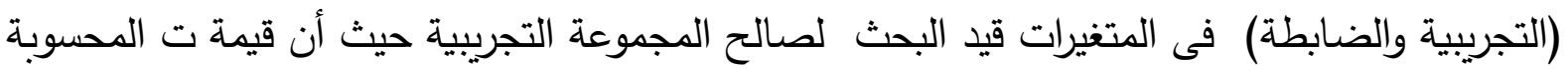

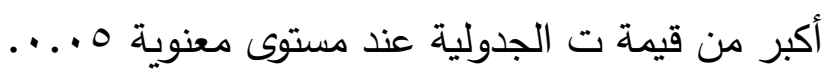

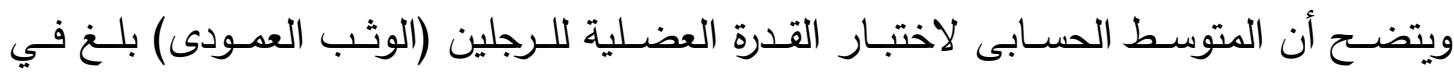

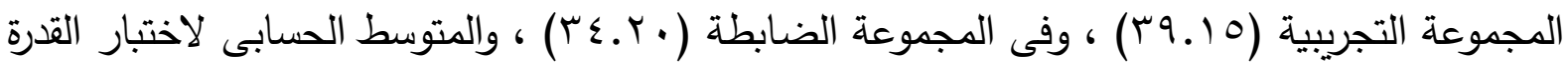

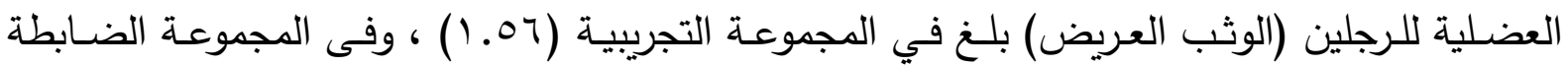


( ، (1) ، والمتوسط الحسابى لاختبار تحمل القوة (ثنى الذراعين) بلغ في المجموعة التجريبية (10.؟ ( )

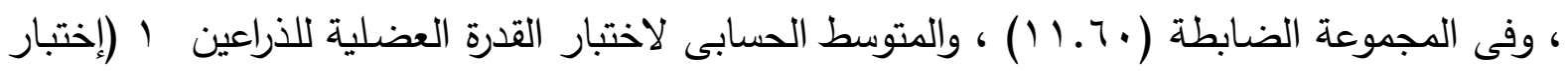

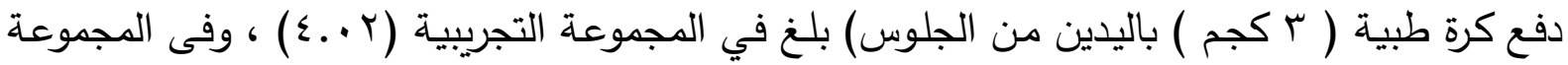

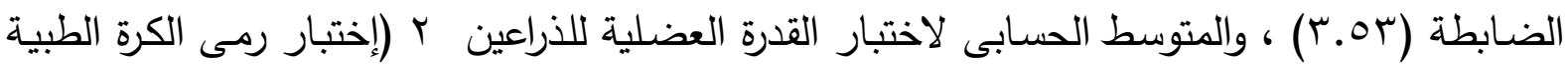

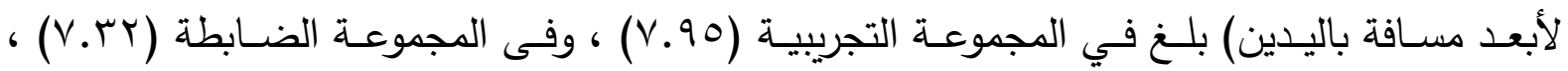

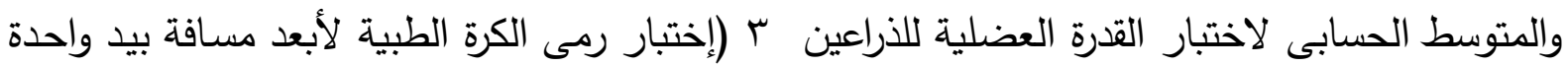

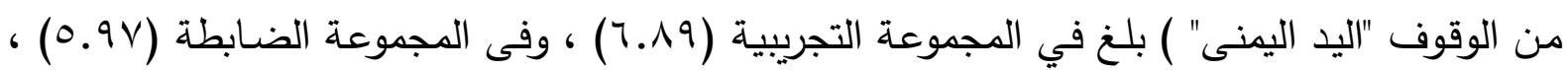

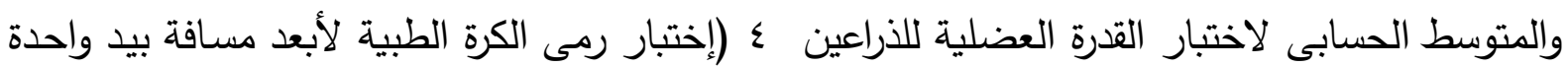

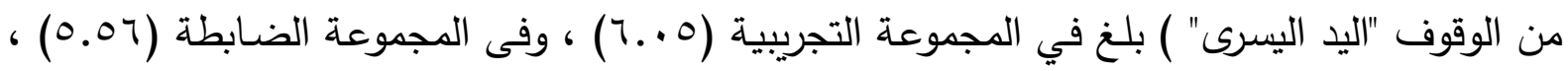

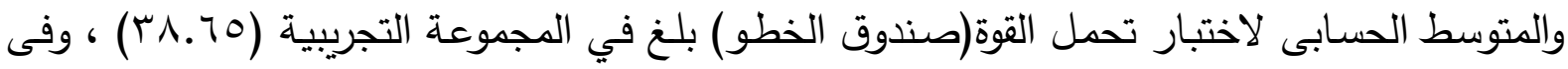

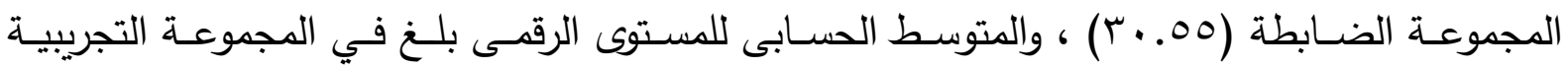

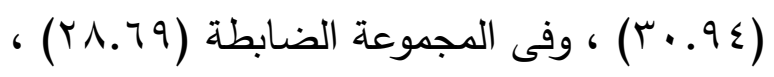

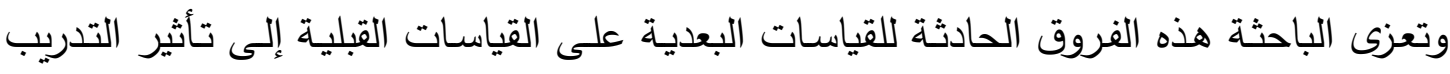

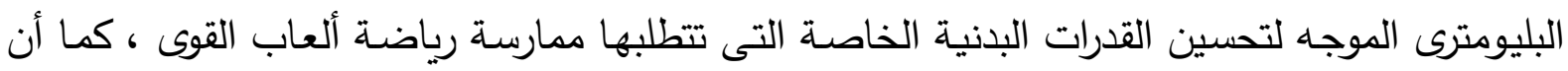
التدريب باستخدام تمرينات مشابهة لطبيعة الأداء المهارى الذى تماريه اللاعبة وذلك باستخدام الوسائل الكائل

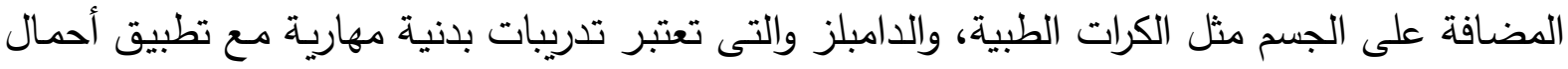
تدريبية مقننة تتناسب مع وزن كل لاعبة من عينة البحث .

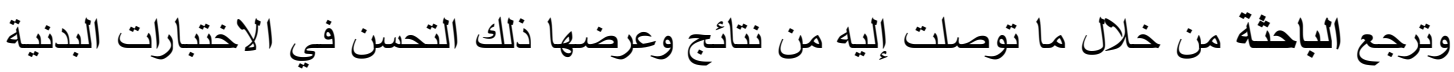

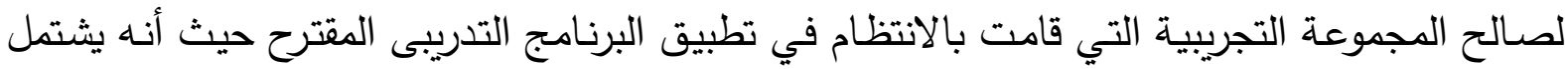

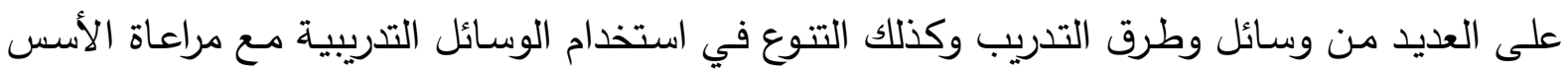

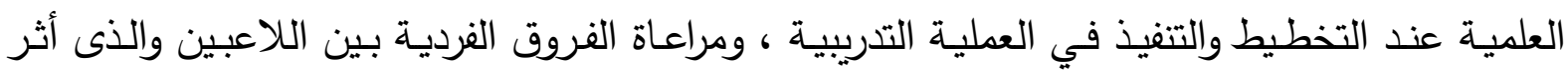

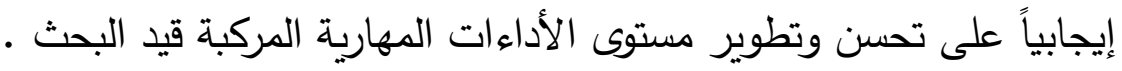

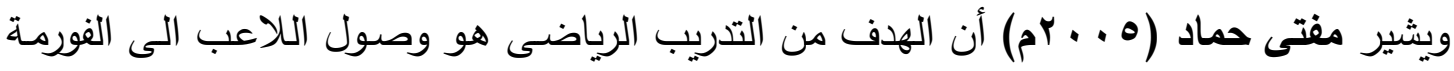

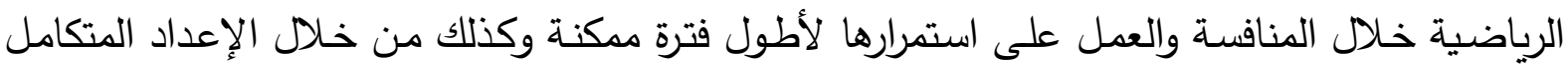

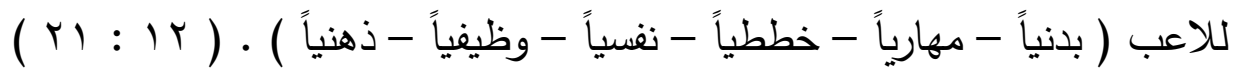

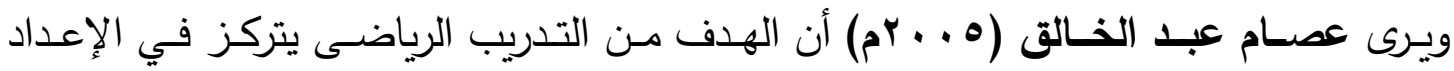

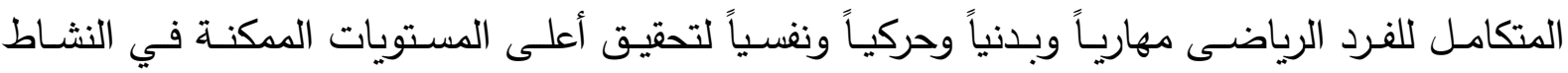

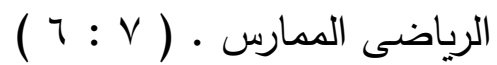

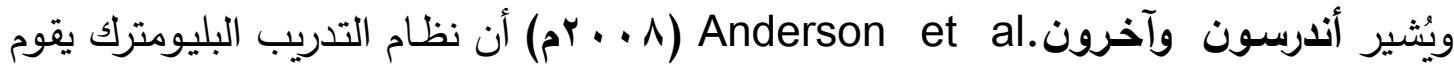

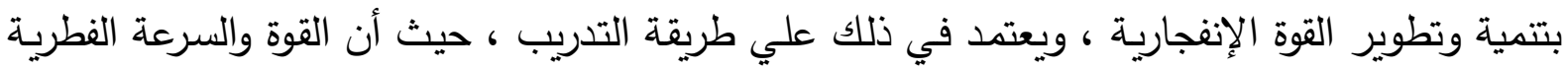

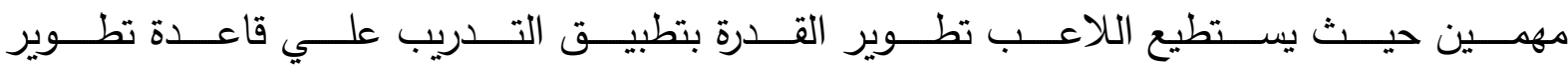




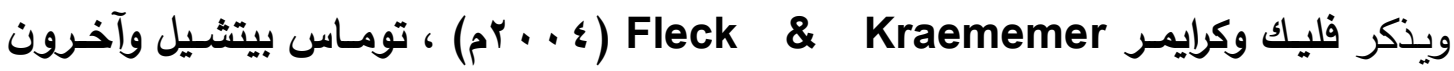
Thomas R Baechle

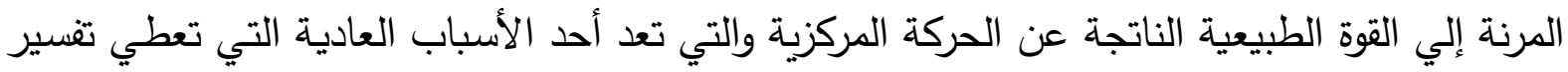

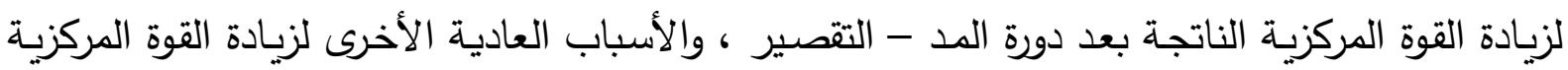
هي رد فعل الإطالة والتي تتتج عن تطويع أكثر الألياف في العضلة المشتركة في الحركة. ( ITV: IV) ، (10:17)

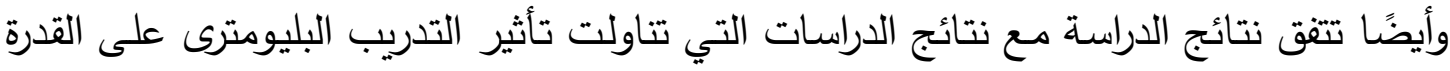

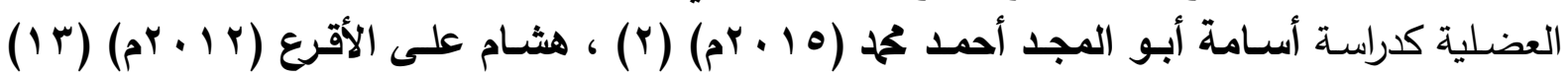

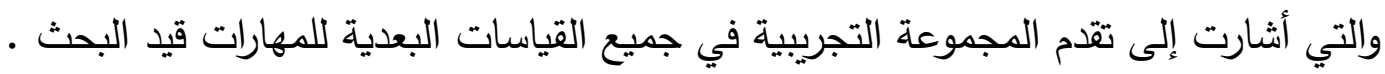

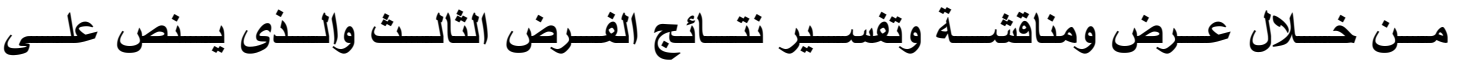

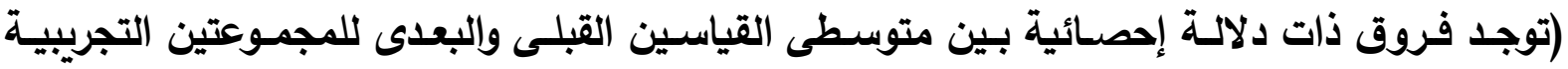

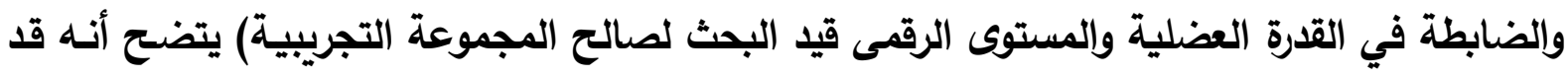
تحقق إجرائياً

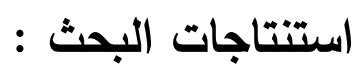

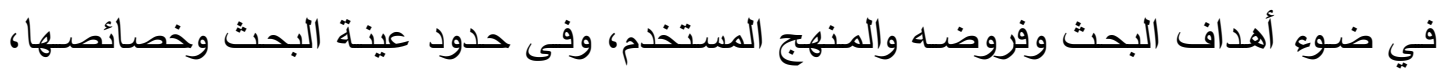

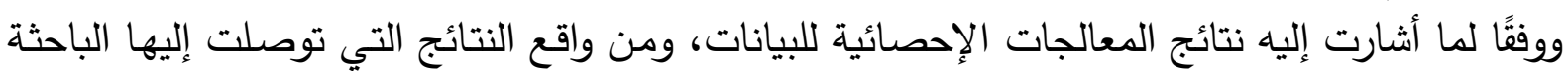

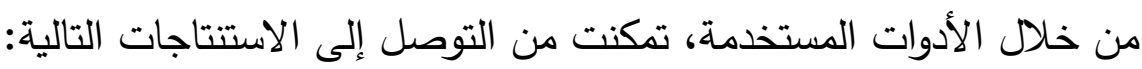

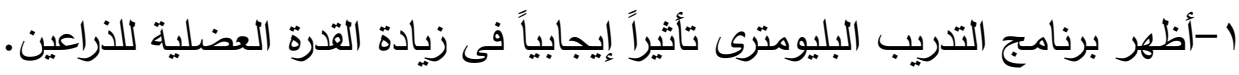

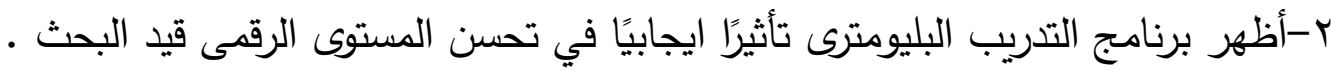

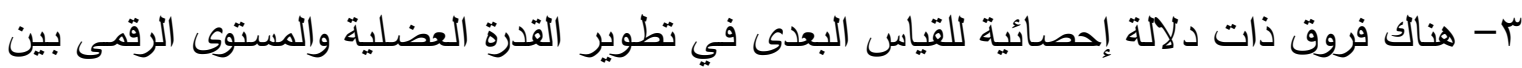

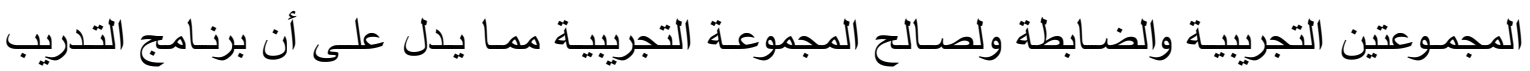

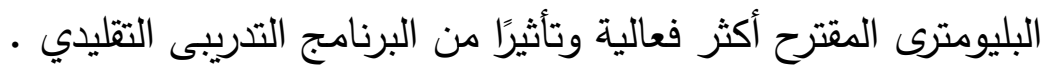

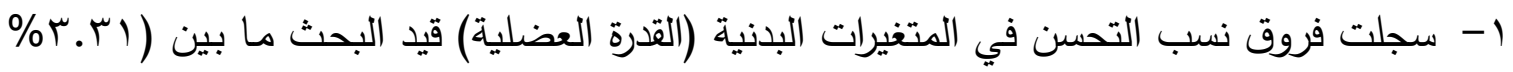

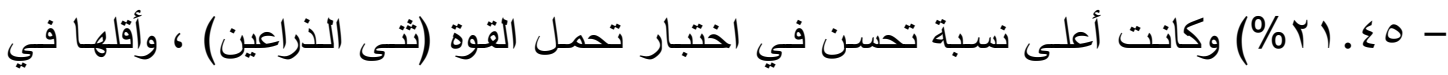
اختبار القدرة العضلية للرجلين (الوثب العريض) ولصالح المجموعة التجريبية.

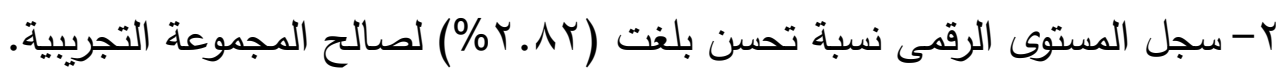
توصيات البحث :

1- تطبيق البرنامج التدريبى المقترح بمحتواه وخصائص تثكيل أحماله على المراحل السنية المختلفة

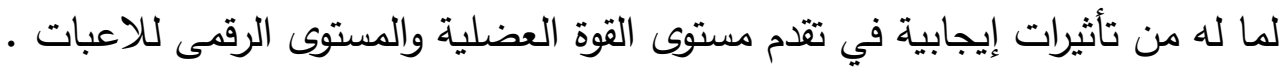

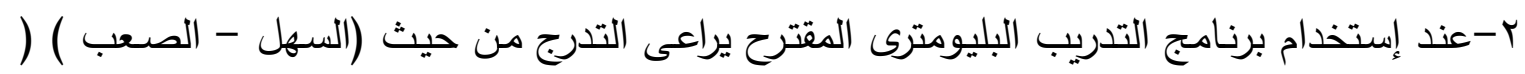

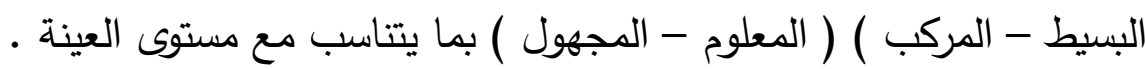

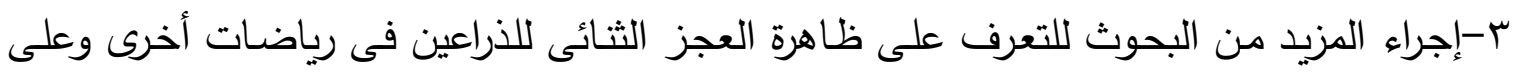
عينات مختلفة من حيث السن والجنس . 
ع-توجيه النتائج المستخلصة من البرنامج التدريبى المقترح وخطوات تتفيذه للعاملين فى مجال تدريب التئي

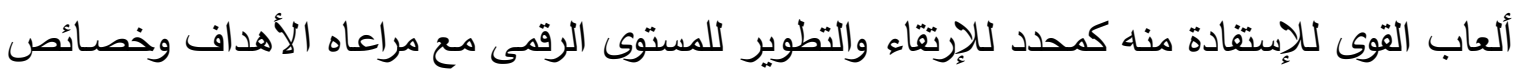
المراحل السنية . 


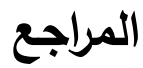

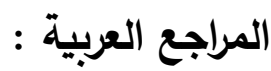

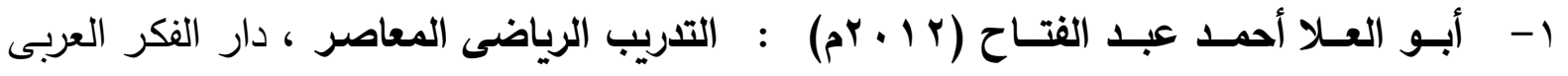

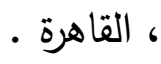

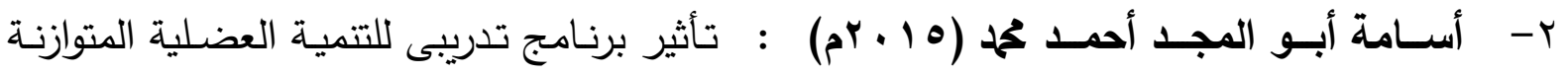

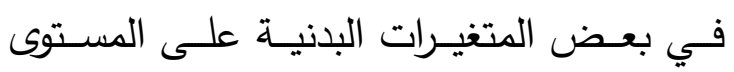

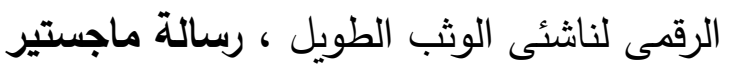

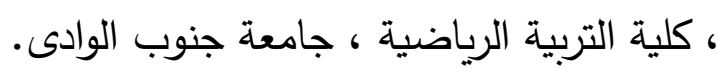

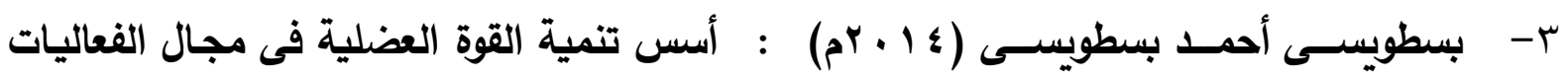

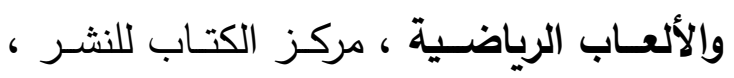

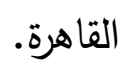

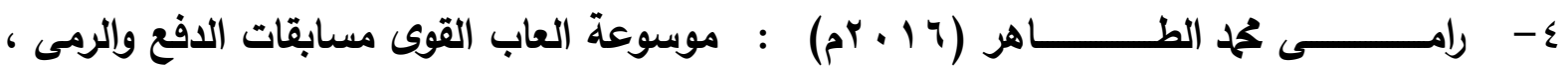

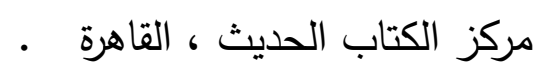

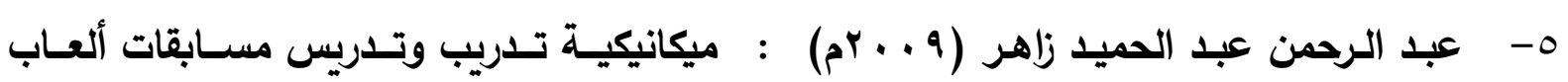

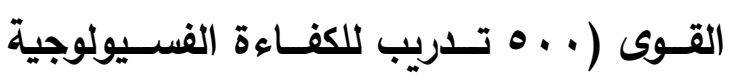
والمهارية) ، مركز الكتاب للنشر ، القاهرة.

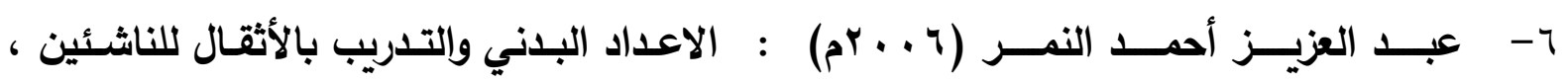

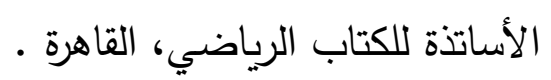

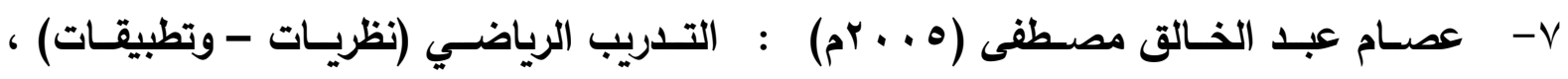

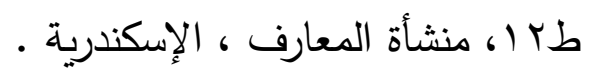

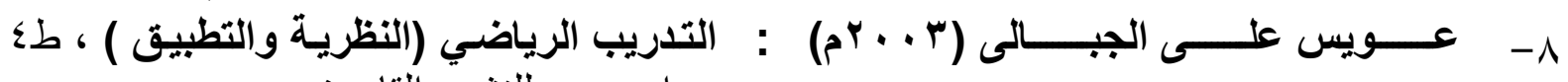

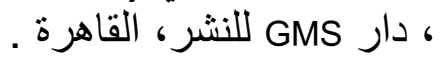

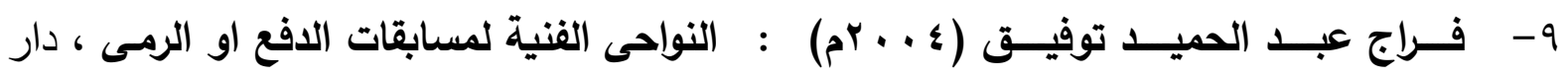

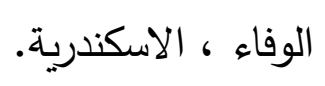

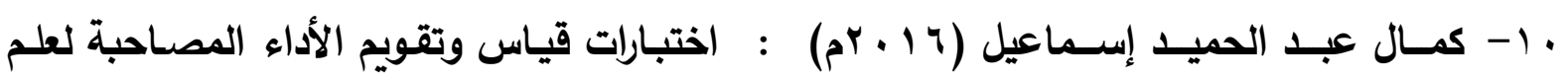
حركة الانسان ، مركز الكتاب للنشر ، القاهرة.

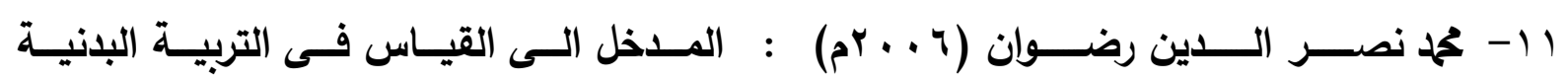
والرياضية ، مركز الكتاب للنشر ، القاهرة.

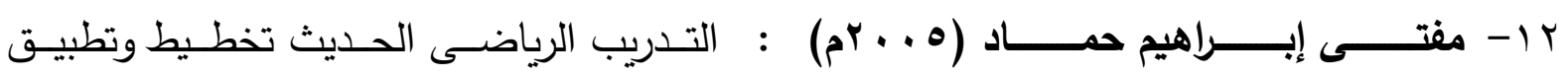
وقيادة ، دار الفكر العبى ، القاهرة . 


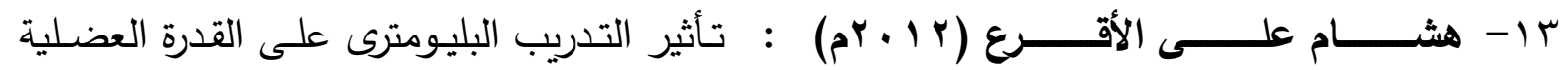
والمستوى الرقمى لكنتخب قطاع غزة بدفع الجلة

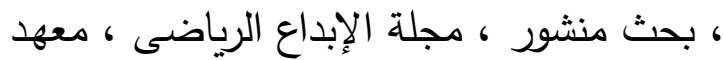

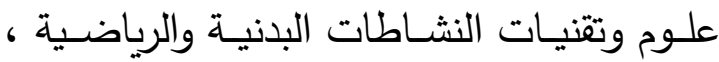

جامعة محمد بوضياف المسيلة .

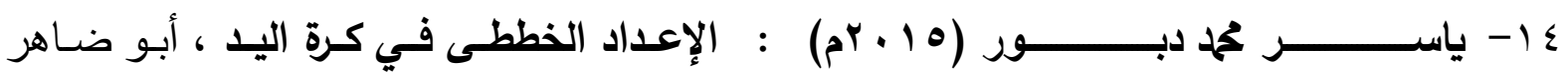

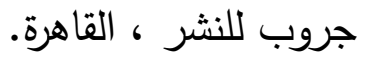

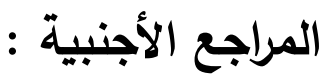

15- Anderson, C. E., Sforzo, G. : The effects of combining elastic and A., \& Sigg, J. A. (2008) free weight resistance on strength and power in athletes. The Journal of Strength \& Conditioning Research, 22(2), 567-574.

16- Fleck S.J., Kramer W.J. : Designing résistance training programs, (2004) 2nd ed., Human Kinetics publisher, Inc., Champaign , Illinois, U.S.A.

17- Thomas $\boldsymbol{R}$ Baechle, Roger : Essentials of strength training and W., Earle and Ban Waten competition 2nd ed., Section 4. Chapter (2000) 18 Human Kinetics. 